\title{
Optical-Based (Bio) Sensing Systems Using Magnetic Nanoparticles
}

\author{
Recep Üzek ${ }^{1}$, Esma Sari ${ }^{2}$ and Arben Merkoçi ${ }^{3,4, *}$ \\ 1 Department of Chemistry, Faculty of Science, Hacettepe University, Ankara 06800, Turkey; \\ ruzek@hacettepe.edu.tr \\ 2 Vocational School of Health Services, Medical Laboratory Techniques, Yüksek İhtisas University, \\ Ankara 06800, Turkey; esma.sari@hotmail.com \\ 3 Catalan Institute of Nanoscience and Nanotechnology (ICN2), CSIC and BIS, Bellaterra, \\ 08193 Barcelona, Spain \\ 4 Catalan Institution for Research and Advanced Studies (ICREA), Pg. Lluís Companys 23, \\ 08010 Barcelona, Spain \\ * Correspondence: arben.merkoci@icn2.cat; Tel.: +34-937374604
}

Received: 23 September 2019; Accepted: 22 October 2019; Published: 25 October 2019

check for updates

\begin{abstract}
In recent years, various reports related to sensing application research have suggested that combining the synergistic impacts of optical, electrical or magnetic properties in a single technique can lead to a new multitasking platform. Owing to their unique features of the magnetic moment, biocompatibility, ease of surface modification, chemical stability, high surface area, high mass transference, magnetic nanoparticles have found a wide range of applications in various fields, especially in sensing systems. The present review is comprehensive information about magnetic nanoparticles utilized in the optical sensing platform, broadly categorized into four types: surface plasmon resonance (SPR), surface-enhanced Raman spectroscopy (SERS), fluorescence spectroscopy and near-infrared spectroscopy and imaging (NIRS) that are commonly used in various (bio) analytical applications. The review also includes some conclusions on the state of the art in this field and future aspects.
\end{abstract}

Keywords: optical sensor; magnetic nanoparticle; imaging; surface plasmon resonance; surface-enhanced Raman spectroscopy; fluorescence spectroscopy; near infrared spectroscopy

\section{Introduction}

In recent years, great interest has been shown in the field of nanotechnology in general and particularly its applications in the manufacturing of novel materials with added magnetic, electrical, optical, and biological properties for various areas. Among these nanomaterials with added properties, magnetic nanoparticles (MNPs) are quite interesting given their unique physico-chemical structure. The plethora of applications has been described for MNPs that are directly associated with modulation of the chemical structure, size distribution, and magnetic moment [1,2]. In addition, MNPs were found to possess a number of intrinsic properties such as biocompatibility, low toxicity, ease of surface modification, chemical stability, high surface area, high mass transference besides others [3]. Although all kind of MNPs, like other nanoparticles, can be used in different ways, size, and surface have a severe impact on the application area. For example, MNPs over $28 \mathrm{~nm}$ are ferrimagnetic and commonly used for magnetic separation and for electronic instruments as ferrofluids. MNPs below $28 \mathrm{~nm}$, on the other side, are super-paramagnetic and are generally preferred for biomedical applications [4].

MNPs are generally divided, regarding their chemical structure, into metal oxides, pure metals, and magnetic nanocomposites. This distinct class of MNPs and application areas are depicted in 
Figure 1. Metal oxides are most commonly used for biomedical applications, such as cell labeling and imaging [5-8], diagnostic and therapeutic agents [9]. Among metal oxides, iron oxides are commonly used since they have better biocompatibility [10]. In contrast to metal oxides, pure metals as a class of MNPs have limited application areas due to their chemical instability [11] and large size distributions [12]. Although rarely reported, the use of pure metal nanoparticles is generally found in electronic devices such as ultra-high-density magnetic storage devices [13-15]. In other respects, the use of magnetic nanocomposites, particularly in a sensor, biosensor and detection systems, has become increasingly common in recent years [16-19]. Disadvantages of MNPs, such as their tendency to aggregate to reduce surface energies, and oxidation in air, are among the major obstacles to the spread of their more frequent use in the applications [20]. Therefore, from the application point of view, researchers have proposed a new approach to the development of new materials by coating polymer, silica or other materials over MNPs, so-called magnetic nanocomposites [21-23].

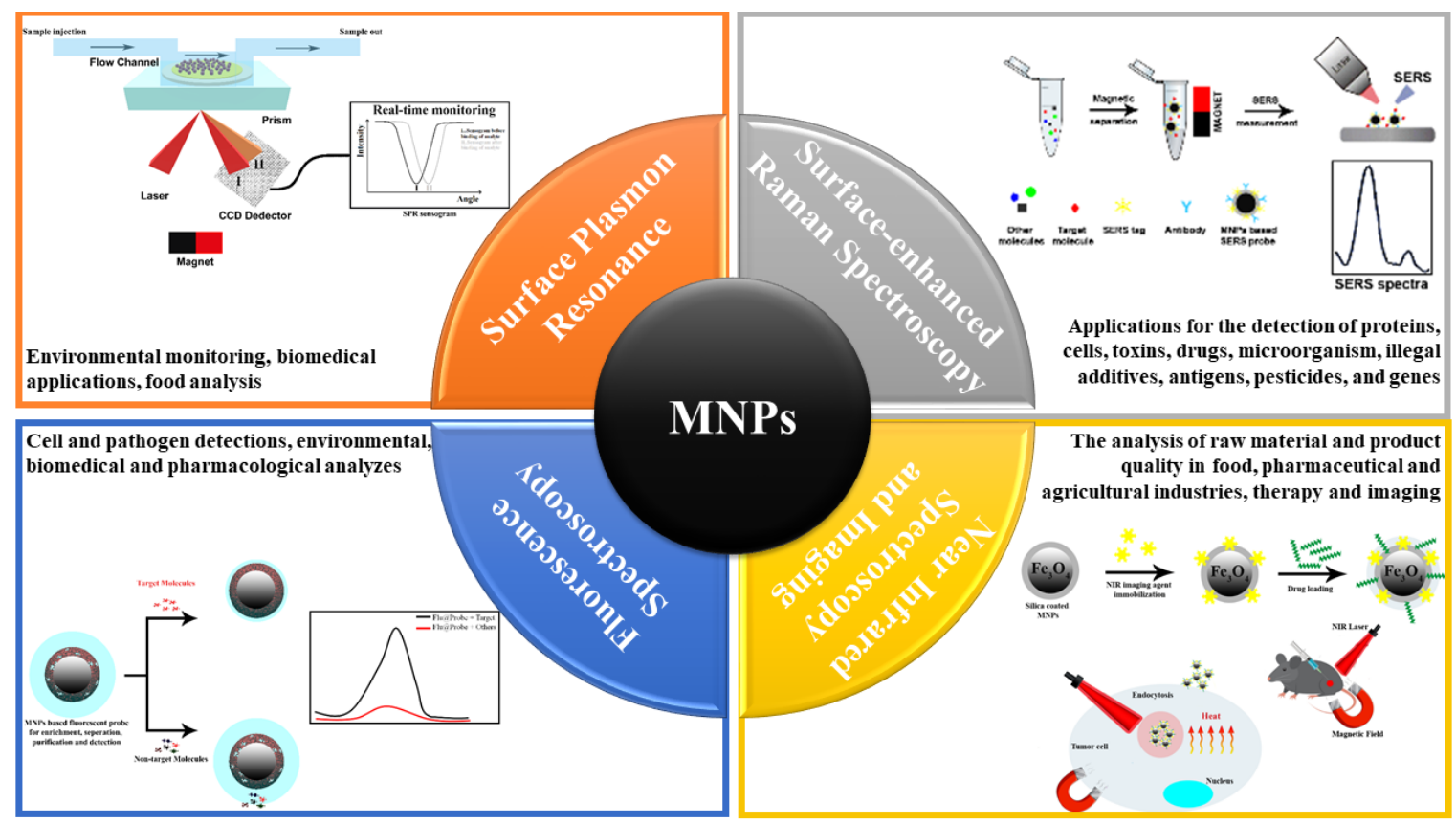

Figure 1. The main applications of optical-based (bio) sensing systems using magnetic nanoparticles (MNPs) in biomedical and environmental fields.

In practice, the feasible features of MNPs are not only affected by their structure but also by their fabrication techniques and surrounding environments [4,24,25]. MNPs can be prepared in the following three routes to suit the final desired application. The majority of these methods are based on the chemical methods or "bottom-up" synthesis procedures, which include co-precipitation, high-temperature thermal decomposition and/or reduction, sol-gel synthesis, flow-injection synthesis, oxidation method, electrochemical method, aerosol/vapor-phase method, supercritical fluid method, and synthesis using nanoreactors $[5,25]$. Chemical synthesis is controllable for almost all the processing conditions, and indeed, there has been a report indicating that this may be one reason for the "popularity" of chemical techniques for synthesis [26]. Alternatively, MNPs can be formed via physical methods through a simple non-chemical "top-down" dispersion technique, e.g., gas-phase deposition and electron-beam lithography $[5,25,27]$. Traditionally, physical methods have been the less preferred synthesis techniques for MNPs given an inability to control the size of particles down to the nanometer scale using these methods [27]. On the other hand, bio-reduction in the so-called microorganism approach, which has allowed large quantities of production, ensures the high yield, good reproducibility, and stability, as well as low cost [5,27]. In optical-based (bio)sensing systems, multifunctional composites such as $\mathrm{Fe}_{3} \mathrm{O}_{4} @ \mathrm{Ag}$, $\mathrm{Fe}_{3} \mathrm{O}_{4} @ \mathrm{Au}$, etc., are mainly prepared by 
two methods: core-shell structure (1) and immobilization on the core (2) [28,29]. In both methods, magnetic nanoparticles are first coated with silica shells to increase the stability of the magnetic nanoparticles and to facilitate their modification. In the first of these directions, Ag or Au is reduced by using chemical compounds such as $\mathrm{NaBH}_{4}$, citric acid, etc. on the surface of the magnetic core. In the second method, gold or silver nanoparticles are prepared in different forms such as spherical, cubes or nanorods and then immobilized to the surface of the magnetic core by physical or chemical methods. In physical immobilization, it is usually carried out by modification of the magnetic core with polymers such as oleic acid, etc., and then bonded to the magnetic surface by the secondary interactions. In chemical immobilization, the surface of magnetic and Au or Ag nanoparticles are first modified with functional groups such as carboxyl or amine, and then the chemical immobilization is performed by modification method such as 1-Ethyl-3-(3-dimethylaminopropyl) carbodiimide/N-hydroxysuccinimide (EDC/NHS) coupling, etc.

After synthesis of MNPs, the common analytical techniques used for the characterization of MNPs are: ultraviolet (UV)-visible spectrophotometry, dynamic light scattering (DLS), scanning electron microscopy (SEM), transmission electron microscopy (TEM), Fourier transform infrared spectroscopy (FTIR), atomic force microscopy (AFM), powder X-ray diffraction (XRD), X-ray fluorescence (XRF) and energy-dispersive spectroscopy (EDS) [30,31].

There is no doubt that the extensive literature that can be associated with the term of biosensor shows that the related field of research is very attractive. In the first approach, a biosensor can be simply defined as a device that intimately combines a biological sensing element with a transducer [32]. In an efficient biosensor design, it is essential to convert the biological interaction to a signal which is transduced by physical, chemical, optical, thermal or electrochemical actions, into observable information and analyzed quantitatively [33]. Even though electrical and electrochemical platforms are the most advanced and used biosensor platforms, these systems have drawbacks owing to the extra reduction/oxidizing agent being involved [34]. While the biosensor can be built in a comparable manner based on optical and electrochemical transducers, it obviously demonstrates distinct working features [32]. Optical biosensors play a prominent role in sensing applications because they have distinct advantages: for example, high-precision detection and label-free design [34]. Optical biosensors also offer the possibility of immune electromagnetic interference, capable of remote sensing, and can perform multiplex detection within a single device [35]. The next generation of sensing equipment for daily use is optical biosensor platforms, based on absorbance, photoluminescence and surface plasmon resonance (SPR) [34]. In addition, coupling the synergistic effects of the optical properties and magnetic properties in a single method may offer new multitasking platforms for (bio)sensing, biolabeling/imaging, cell sorting/separation, and photothermal therapy [36].

In this comprehensive review, we will discuss optical biosensing systems based on the use of MNPs. Under this category, there exist a number of optical-sensing methods by using MNPs, including SPR, surface-enhanced Raman spectroscopy (SERS), fluorescence spectroscopy and near-infrared spectroscopy and imaging (NIRS).

\section{Surface Plasmon Resonance (SPR)}

Surface plasmon resonance (SPR) is a complex physical phenomenon occurring on an electrically conductive noble metal layer at the interface between two media (i.e. high refractive indices of sensor's glass surface and low refractive indices of buffer) when p-polarized light under conditions of total internal reflection $[37,38]$. Interest in the SPR effect started with an explanation as the energy of photons absorbed by the free electrons of the metallic layer reduced the amplitude of the incident light that comes with a certain angle. Despite the SPR effect being successfully explained in 1968, SPR as a method of determination in the field of biosensor was first mentioned in 1983 by Wijaya et al. Although fluorescence or absorbance based optical methods have been used since earlier times, SPR as surface-based optical method has been developed very rapidly and has attracted considerable interest in biosensing platform [38]. Investigation of biomolecular interactions with SPR is considered 
an exceedingly powerful analysis method due to SPR's remarkable properties as an analytical tool such as its label-free nature, real-time, highly precise, a short time and simplicity. Despite the usefulness of SPR, the conventional SPR methods are mainly hampered by the detection of low concentration, low molecular weight biomolecules due to trivial changes of the refractive index in the binding process. Several approaches to overcome this challenge have been offered by researchers based on the use of nanoparticles $[39,40]$. Until now, decorating SPR surfaces with MNPs seems to be the most widely attested. Especially the application of MNPs in SPR sensing has attracted great focus owing to advantages which are (1) capture of the target molecules from the complex sample and (2) high refractive index and high molecular weight of MNPs to recruit the SPR signal [41,42]. Due to the aforementioned desired properties of MNPs, these compounds are widely used for environmental monitoring, biomedical applications, food analysis, etc. [43-46]. The principle of the SPR system with MNPs was illustrated in Figure 2 [47].

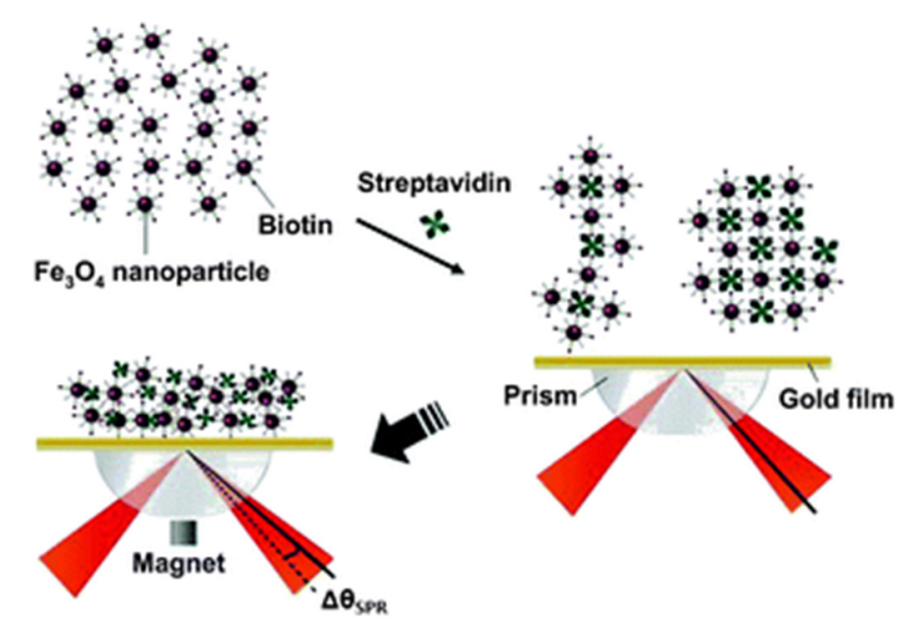

Figure 2. Amplification of the surface plasmon resonance (SPR) response signal with MNPs [47]. Reproduced with permission of the Royal Society of Chemistry.

In 2018, Sun and co-workers reported the SPR biosensor based on hollow gold nanospheres and improved sandwich assay with magnetic nanoparticles to detect rabbit IgG. While the reduced graphene layer (rGO) was covered with Ag nanoparticles to obtain SPR surface, $\mathrm{Fe}_{3} \mathrm{O}_{4} \mathrm{MNPs}_{\text {sere }}$ utilized to capture the analyte of interest easily from the medium. In order to bind the antibody to the surface without modification and avoid agglomeration of nanoparticles, polydopamine (PDA) was used. These researchers showed that the detection of rabbit IgG by gold nanostructures resulted in the 132 times lower concentration when compared with a conventional SPR biosensor. The changes in the SPR signal caused by the magneto-sandwich immunoassay were further compared with the signal of hollow gold nanospheres. Their investigation showed that the 8 times higher enhancement in the SPR signal was related to the magneto-sandwich immunoassay [48]. In another study, aptamer immobilized SPR-based biosensors were developed by utilizing core-shell AuNPs and MNPs (MNPs) as the plasmonic coupling partners for the detection of thrombin as a model analyte. Aptamer immobilized AuNPs-MNPs conjugate-based SPR biosensors exhibited a considerable response to the thrombin with the limits of detection (LOD) of $0.6 \mathrm{nM}$. As compared to the SPR signal shift with a control group that is based on SPR signal without AuNPs-MNPs conjugate, AuNPs-MNPs conjugate based SPR angle shift was enlarged for 5 times at the $100 \mathrm{nM}$ concentration [49]. A summary of the different applications of the MNPs by combining the synergistic effects of the SPR is summarized in Table 1. 
Table 1. Examples of the application of MNPs in SPR system.

\begin{tabular}{|c|c|c|c|c|}
\hline Magnetic Part & SPR System & Applications & Advantages & [R] \\
\hline $\begin{array}{l}\text { Active layer consisting of } \mathrm{Fe}_{3} \mathrm{O}_{4}+ \\
\text { Polyethylene glycol (PEG4000) }\end{array}$ & Silver-coated prism-coupled SPR System & Plant DNA & $\begin{array}{c}\text { Target analyte could not be detected without using a } \\
\text { magnetic part. }\end{array}$ & [50] \\
\hline $\begin{array}{l}\text { Polydopamine- } \mathrm{Ag} \text { capped } \mathrm{Fe}_{3} \mathrm{O}_{4} \mathrm{NPs} \\
\text { reduced with graphene oxide }\end{array}$ & $\begin{array}{l}\text { Gold film of SPR chip was } \\
\text { electromagnetically coupled with hollow } \\
\text { gold nanoparticles }\end{array}$ & Rabbit IgG & $\begin{array}{l}\text { Detection limit } 132 \text { times lower than conventional SPR } \\
\text { and } 8 \text { times lower than immunosandwich assay. }\end{array}$ & [48] \\
\hline $\begin{array}{c}\text { Gold capped } \mathrm{Fe}_{3} \mathrm{O}_{4} \\
\text { nanoparticles (GMNPs) }\end{array}$ & Conventional SPR system with gold chip & Thrombin & $\begin{array}{l}\text { SPR angle shift is enlarged for } 5 \text { times comparing with } \\
\text { that of control group without GMNPs }\end{array}$ & [49] \\
\hline MNPs conjugated with antibody & Conventional SPR system with gold chip & Pathogenic Bacteria & $\begin{array}{c}\text { MNPs offer a sensing enhancement of } 4 \\
\text { orders of magnitude. }\end{array}$ & [51] \\
\hline $\begin{array}{l}\text { Magneto plasmonic nanoparticles } \\
\text { (core shell gold capped MNPs) }\end{array}$ & Conventional SPR system & $\begin{array}{l}\text { Antigen (Tuberculosis } \\
\text { marker protein) }\end{array}$ & $\begin{array}{l}\text { Implementation of magneto-plasmonic NPs outcomes in } \\
\text { 30-fold extension of the SPR signal at the limit of detection. }\end{array}$ & [52] \\
\hline $\begin{array}{l}\text { Nanohybrids containing } \mathrm{Fe}_{3} \mathrm{O}_{4} \mathrm{NPs} \\
\text { and hollow gold sphere nanoparticles. }\end{array}$ & $\begin{array}{l}\text { SPR chip coated with carboxyl } \\
\text { functionalized graphene oxide sheet. }\end{array}$ & Human IgG & $\begin{array}{l}\text { Detection limit is approximately } 260 \text {-fold lower than that } \\
\text { acquired with sandwich assay by routine SPR biosensors. }\end{array}$ & [53] \\
\hline $\begin{array}{l}\text { Polydopamine-wrapped magnetic } \\
\text { multi-walled carbon nanotubes }\end{array}$ & $\begin{array}{l}\text { Capture antibody-immobilized } \\
\text { SPR-sensing film modified by hollow } \\
\text { gold nanoparticles and polydopamine }\end{array}$ & $\begin{array}{l}\text { Protein (Human cardiac } \\
\text { troponin I, CTnI) }\end{array}$ & $\begin{array}{l}\text { Minimum detectable SPR response for the concentration } \\
\text { of target molecule is } 1000 \text { times lower than that achieved } \\
\text { by the traditional SPR immunoassay. }\end{array}$ & [54] \\
\hline $\begin{array}{l}\text { Magnetic fluid photonic crystal } \\
\text { (i.e. kind of colloid compassed of MNPs } \\
\text { dispersed in carrier liquid) }\end{array}$ & $\begin{array}{l}\text { Kretschmann configuration (prism } \\
\text { coupling) SPR system. }\end{array}$ & & $\begin{array}{l}\text { The excellent benefit of elevated sensitivity is with the } \\
\text { combination of magnetic fluid photonic crystal and SPR. }\end{array}$ & [55] \\
\hline $\begin{array}{c}\text { Aptamer-immobilized } \mathrm{Fe}_{3} \mathrm{O}_{4} \\
\text { nanoparticles with organic clusters }\end{array}$ & $\begin{array}{l}\text { Kretschmann configuration (prism } \\
\text { coupling) SPR system. }\end{array}$ & $\begin{array}{l}\text { Protein (prion disease associated } \\
\text { isoform, } \operatorname{PrP} \mathrm{P}^{\mathrm{SC}} \text { ) }\end{array}$ & $\begin{array}{l}\text { The SPR scheme involves magnetic NPs-organic clusters } \\
\text { that allow for a } 215 \text {-fold rise in the immediate SPR signal. }\end{array}$ & [46] \\
\hline Streptavidin-coated MNPs & $\begin{array}{l}\text { Grating-coupled SPR (GC-SPR) with } \\
\text { wavelength interrogation. }\end{array}$ & Lipid (Extracellular vesicles, EVs) & $\begin{array}{l}\text { Target could not be detected with the direct SPR detection } \\
\text { platform at such low concentrations. }\end{array}$ & [56] \\
\hline Fe-C core shell-aptamer conjugation & Prism-coupling SPR system & $\begin{array}{l}\text { Protein (prion disease associated } \\
\text { isoform, } \operatorname{PrP} \mathrm{P}^{S C} \text { ) }\end{array}$ & $\begin{array}{l}\text { The detection sensitivity of } \operatorname{PrP}^{\mathrm{SC}} \text { has been improved by } \\
\text { about } 10 \text { times relative to the direct format of } \\
\text { SPR detection. }\end{array}$ & [57] \\
\hline Antibody-functionalized MNPs & $\begin{array}{l}\text { Antibody-immobilized SPR } \\
\text { immunoassay }\end{array}$ & Hormone (Estradiol) & $\begin{array}{c}\text { The MNPs showed outstanding ability to amplify } \\
\text { the SPR signal. }\end{array}$ & [45] \\
\hline PEG-4000 functionalized $\mathrm{Fe}_{3} \mathrm{O}_{4}$ MNPs & $\begin{array}{l}\text { SPR set up device in Kretschmann } \\
\text { configuration and He/Ne laser beam. }\end{array}$ & Microalgae & $\begin{array}{l}\text { Microalgae population has been successfully monitored } \\
\text { with the proposed system. }\end{array}$ & [58] \\
\hline MNPs antibody conjugates & Conventional SPR spectroscopy & Cancer Biomarkers & $\begin{array}{l}\text { To differentiate ovarian cancer, this multiplexed scheme } \\
\text { accomplished sensitivity and specificity of up to } 94 \% \text { and } \\
98 \% \text {, respectively. }\end{array}$ & [59] \\
\hline
\end{tabular}




\section{Surface-Enhanced Raman Spectroscopy (SERS)}

Surface-enhanced Raman scattering (SERS) based on the enhancement of molecular Raman scattering by surface plasmons after the interaction between light and nanostructures is a surface-sensitive technique that is used for the detection of target with high molecular sensitivity and specificity at ultra-trace concentrations, including single molecules and provides more details on the chemical structure and conformation of target molecule [60]. The enhancement of the Raman signal is explained by two mechanisms: chemical enhancement arising from the charge transfer between the nanostructures and the adsorbed target and electromagnetic enhancement stemming from the electromagnetic field effect of the adsorbed target by stimulating the surface plasmons of nanostructures [61,62]. Since the enhancement of molecular Raman scattering mainly occurred by electromagnetic enhancement, novel nanostructures have been developed to achieve high enhancement factors by changing the plasmonic properties. The surface plasmons of nanostructures can be changed with the physical and chemical properties of nanostructures such as shape, size, type, and composition, etc. thus directly affecting the sensitivity and selectivity of SERS [63]. Because of their higher enhancement factors and the accessibility of plasmonic resonances in the visible and NIR areas, the plasmonic nanostructures (PNS) based on Au and Ag are most often preferred to produce SERS substrate [64]. Because of their higher enhancement factors and the accessibility of plasmonic resonances in the visible and NIR areas, the plasmonic nanostructures based on $\mathrm{Au}$ and $\mathrm{Ag}$ are most often preferred to produce SERS substrates. The SERS substrates have been successfully manufactured for the detection of targets such as biomolecules, cells, microorganisms, environmental pollutants, etc.

Although SERS has many important advantages, there are still needs for improvement of the reproducibility and stability of SERS substrates and the analysis of biological fluids and real environmental samples. These improvements can be achieved using MNPs or magnetic nanocomposites because of their unique properties such as strong superparamagnetic property, low toxicity, biocompatibility, easy preparation, and high adsorption ability. As outlined in Table 2, MNPs in SERS analysis have been used for the detection of proteins [65-68], cells [69-71], toxins [72], drugs [73,74], microorganisms [75-78], illegal additives [79,80], antigens [81,82], pesticides [83], and genes $[84,85]$. 
Table 2. Selected examples of surface-enhanced Raman spectroscopy (SERS) sensors based on MNPs.

\begin{tabular}{|c|c|c|c|c|c|c|c|}
\hline Type of PNS & Size of PNS, nm & Forms of MNPs & Size of MNPs, nm & Reporter $^{1}$ & Analyte & Detection limit & [R] \\
\hline $\mathrm{Au}$ NPs & 15 & $\begin{array}{c}\gamma-\mathrm{Fe}_{2} \mathrm{O}_{3} \text { covered with silica shell and } \\
\text { polymer shell }\end{array}$ & 64 & DTNB & Tau protein & $25 \mathrm{fM}$ & [65] \\
\hline Au NPs & 20 & $\begin{array}{c}\gamma-\mathrm{Fe}_{2} \mathrm{O}_{3} \mathrm{MNPs} \text { covered with silica and } \\
\text { Au shell }\end{array}$ & 160 & DTNB & Telomerase activity & $1 \mathrm{cell} / \mathrm{mL}$ & [67] \\
\hline $\begin{array}{c}\text { Triangular Ag } \\
\text { nanoprisms }\end{array}$ & 40 & $\gamma-\mathrm{Fe}_{2} \mathrm{O}_{3}$ MNPs MNPs & 21 & MBA & Tumor cells & $1 \mathrm{cell} / \mathrm{mL}$ & [69] \\
\hline Au NPs & 20 & $\gamma-\mathrm{Fe}_{2} \mathrm{O}_{3}$ covered with silica shell & 25 & MBA & Microcystin-LR & $2.0 \mathrm{pg} / \mathrm{mL}$ & [72] \\
\hline Au NPs & 20 & $\begin{array}{l}\mathrm{Fe}_{3} \mathrm{O}_{4} \text { magnetic microspheres covered with } \\
\mathrm{SiO}_{2} \text { shell and Au nanoparticles }\end{array}$ & 500 & Cyanine & Sildenafil citrate & $10 \mathrm{nM}$ & [74] \\
\hline Au NPs & 31 & $\gamma-\mathrm{Fe}_{2} \mathrm{O}_{3}$ encapsulated with polymer & 330 & MBA and DSNB & S. typhimurium & 10 cells $/ \mathrm{mL}$ & [77] \\
\hline Au NPs & 30 & $\gamma-\mathrm{Fe}_{2} \mathrm{O}_{3}$ MNPs & 500 & DP & Chloramphenicol & $1.0 \mathrm{pg} / \mathrm{mL}$ & [79] \\
\hline Ag NPs & 20 & $\mathrm{Fe}_{3} \mathrm{O}_{4}$ MNPs covered with $\mathrm{GO}$ and Ag NPs & 500 & - & Chloramphenicol & $0.1 \mathrm{nM}$ & [80] \\
\hline Au NPs & 60 & ParaMNPs & 200 & IR-792 and NB & $\begin{array}{l}\text { West Nile virus Antigen and } \\
\text { Rift Valley fever virus Antigen }\end{array}$ & $5 \mathrm{fg} / \mathrm{mL}$ & [81] \\
\hline $\mathrm{Au} \mathrm{NPs}$ & 30 & $\gamma-\mathrm{Fe}_{2} \mathrm{O}_{3} \mathrm{MNPs}$ & 500 & DP & PSA antigen & $5 \mathrm{pg} / \mathrm{mL}$ & [82] \\
\hline $\mathrm{Ag} / \mathrm{SiO}_{2}$ core-shell NPs & 35 & $\gamma-\mathrm{Fe}_{2} \mathrm{O}_{3} \mathrm{MNPs}$ covered with silica shell & 50 & Rhodamine B & DNA & $5 \mu \mathrm{M}$ & [84] \\
\hline Ag shell & 30 & $\gamma-\mathrm{Fe}_{2} \mathrm{O}_{3}$ MNPs covered with Ag shell & 300 & Cyanine & miRNA & $0.3 \mathrm{fM}$ & [85] \\
\hline Ag shell & 8 & $\gamma-\mathrm{Fe}_{2} \mathrm{O}_{3}$ MNPs covered with Ag shell & 300 & PATP & Thiram & $1.0 \mathrm{nM}$ & [86] \\
\hline $\mathrm{Au} @ \mathrm{Ag}$ core-shell NPs & 32 & $\gamma-\mathrm{Fe}_{2} \mathrm{O}_{3} \mathrm{MNPs}$ covered with polymer shell & 36 & MBT & Kanamycin & $2 \mathrm{pg} / \mathrm{mL}$ & [87] \\
\hline $\mathrm{Ni@Au} \mathrm{and} \mathrm{Ni@Ag} \mathrm{NPs}$ & 212 and 222 & Ni MNPs & 89 & rhodamine $6 \mathrm{G}$ & rhodamine $6 \mathrm{G}$ & $1 \mathrm{mM}$ & [88] \\
\hline Au Shell & 35 & $\gamma-\mathrm{Fe}_{2} \mathrm{O}_{3}$ MNPs covered with Au shell & 50 & - & Microcystin-LR & $3 \mathrm{fM}$ & [89] \\
\hline Au Shell & 15 & $\mathrm{Fe}_{3} \mathrm{O}_{4} \mathrm{MNPs}$ covered with $\mathrm{Au}$ shell & $17-30$ & pthiocresol & Pthiocresol & $4.5 \mathrm{pM}$ & [90] \\
\hline $\begin{array}{l}\text { Au nanocubes and } \\
\text { nanospheres }\end{array}$ & 51 & DNA modified $\mathrm{Fe}_{3} \mathrm{O}_{4}$ magnetic beads & 1000 & Cyanine & DNA & $1 \mathrm{pM}$ & [91] \\
\hline $\begin{array}{l}\text { Silver layers on } \\
\text { reporter-coated AuNPs }\end{array}$ & 60 & Protein $\mathrm{G}$ modified $\mathrm{Fe}_{3} \mathrm{O}_{4}$ magnetic beads & 1000 & $\begin{array}{l}\text { MBA, DTNB, and } \\
\text { TFMBA }\end{array}$ & Cytokines & $4.5 \mathrm{pg} \mathrm{mL}$ & [92] \\
\hline
\end{tabular}

${ }^{1}$ DTNB: 5,5-dithiobis(2-dinitrobenzoic acid); DP: 4,4'-dipyridyl; MBA: 4-Mercaptobenzoic acid; NB: Infrared-792(IR-792) and Nile blue; PATB: p-aminothiophenol. 
As mentioned above, gold $(\mathrm{Au})$ nanostructures in the manufacture of SERS substrates are one of the most widely used metallic nanostructures for the plasmonic substrate. As an example, Zengin et al. [65] applied a sandwich assay for the ultrasensitive detection of tau protein by using monoclonal anti-tau immobilized hybrid MNPs as a probe and polyclonal anti-tau functionalized Au nanoparticles as SERS tags. Firstly, MNPs $\left(\gamma-\mathrm{Fe}_{2} \mathrm{O}_{3}\right)$ were coated with silica for easy modification and then the hybrid structure was coated with polymer shell by Reversible Addition-Fragmentation chain Transfer (RAFT) polymerization. After the modification of the polymer shell, the monoclonal anti-tau was immobilized on the surface of the hybrid MNPs to obtain the capture probe. Gold nanoparticles were synthesized by citrate reduction with a diameter of $15 \pm 8 \mathrm{~nm}$ and then, the gold nanoparticles were first modified with a layer of Raman reporter, 5,5-dithiobis(2-dinitrobenzoic acid) (DTNB) to obtain the homogeneous sandwich assay. Finally, their surfaces were functionalized with polyclonal anti-tau to prepare SERS tags. In this study, the MNPs used in sandwich assay provided easy and rapid detection of the tau protein with a detection limit of $25 \mathrm{fM}$. As another example, Yang et al. [79] performed a similar approach for the detection of chloramphenicol (CAP) by using magnetic separation. For the preparation of SERS tags, gold nanoparticles were first modified with 4,4'-dipyridyl (DP) as SERS reporter and then functionalized with chloramphenicol-bovine serum albumin (BSA) conjugate. CAP antibody was immobilized on the surface of carboxyl-functionalized magnetic beads (average diameter $500 \mathrm{~nm}$ ) by EDC/NHS coupling reaction for magnetically and selectively separation of CAP. The limit of detection was obtained as $1.0 \mathrm{pg} / \mathrm{mL}$ for CAP in aqueous solution and also this SERS immunosensor system based on MNPs was applied to detect CAP in real samples and CAP was detected in the CAP concentration range of $0-5 \times 10^{5} \mathrm{pg} / \mathrm{mL}$. The selectivity experiment and real sample analysis indicate that this immunosensor is fast, sensitive and specific for the detection of CAP in the aqueous solution. As an example of toxin analysis, He et al. [72] developed an aptasensor based on SERS with MNPs for the detection of microcystin-LR (MC-LR) (Figure 3). After the synthesis of Au nanoparticles, its surface was modified with SERS reporter, MBA and then functionalized with MC-LR aptamer as SERS probe. MNPs were first covered with silica for easy immobilization of biomolecule and then the complementary DNA to MC-LR aptamer was immobilized on the surfaces of MNPs by biotin/avidin affinity as a capture probe. The developed aptasensor based on magnetic SERS was successfully applied to the selective and specific detection of MC-LR in tap water with the limit of detection, $2.0 \mathrm{pg} / \mathrm{mL}$. As another approach, Yang et al. [81] developed an aptasensor based on magnetic SERS for the detection of prostate-specific antigen (PSA). PSA-aptamer was immobilized on the surface of the magnetic nanoparticle by EDC/NHS coupling reaction for the specific separation of PSA in the matrix. Au NPs were functionalized with DNA of PSA-complementary as a signal probe. The sandwich assay was applied for detection of PSA and LOD was obtained as $5.0 \mathrm{pg} / \mathrm{mL}$ and $25 \mathrm{pg} / \mathrm{mL}$ in aqueous solution and human serum, respectively. In another study for the detection of antigens, Neng et al. [82] performed the multiplex detection of antigens by using two sets of a spectrally distinct reporter for the preparation of the SERS probe. For the preparation of the SERS probe, the Raman reporter dyes Infrared-792 (IR-792) and Nile blue (NB) were bound separately on the surface of Au NPs and IR-792-coated Au NPs were modified with anti-E IgG and the NB-coated Au NPs were functionalized with anti-N IgG for specific recognition of each target antigen. For capture probe, paramagnetic nanoparticles were first coated with silica and then functionalized with anti-E and anti-N IgG. Briefly, the following procedure was applied for the assay: the antigens were first separated magnetically with the capture probe and then mixed with the antigen modified Au NPs. In the developed SERS sensor, LOD was around $5 \mathrm{fg} / \mathrm{mL}$ for both antigens. This study demonstrated the suitability of magnetic particles in SERS for the multiple detection of targets. In a study to examine the performance of SERS based on MNPs in the detection of microorganisms, polymeric MNPs were synthesized as a capture probe and Au NPs were modified with SERS reporter and specific antibody for the detection of S. typhimurium in the food product [77]. MBA (4-mercapto benzoic acid) and 5,5'-dithiobis(succinimidyl-2-nitrobenzoate) (DSNB) were used as SERS reporter. After the application of sandwich assay for the detection of microorganism, the limit of detection (LOD) of MBA and DSNB 
was obtained as 100 cells $/ \mathrm{mL}$, and 10 cells/mL, respectively, in a spiked food product. The enhanced sensitivity of DSNB as a SERS reporter is due to its molecular characteristics that provide higher Raman scattering. In this study, higher reproducibility is obtained as it provides better solubility in water by coating the magnetic cores with polymer film.

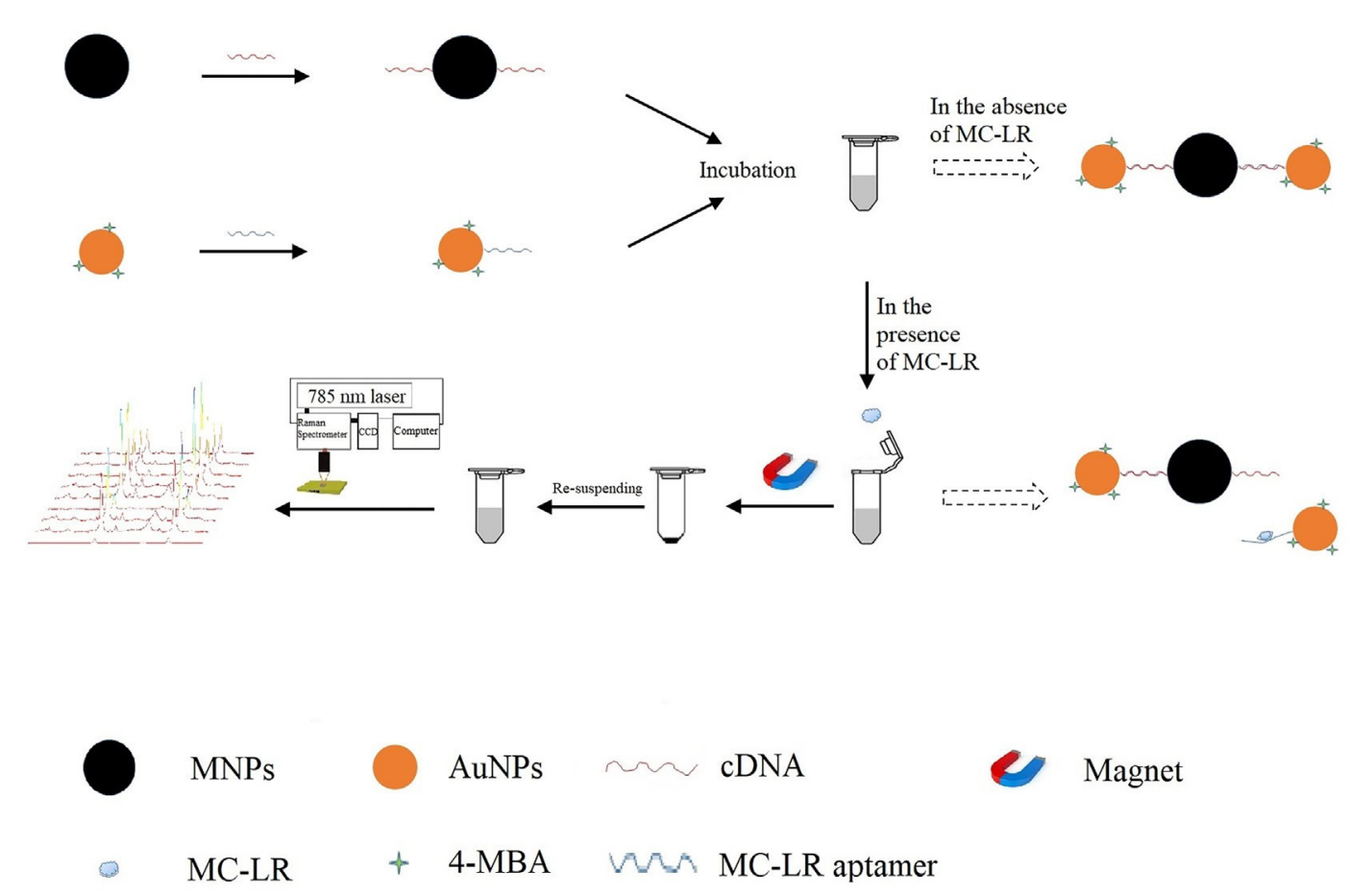

Figure 3. Illustration of the principle for the analysis of microcystin-LR (MC-LR) based on the SERS-based aptasensor. Reprinted [72] (C) 2019, with permission from Elsevier.

In SERS substrate, the other widely used nanostructures are silver nanostructures to create plasmonic surfaces. As an example, Liang et al. [84] developed a DNA hybridization assay based on magnetic SERS for DNA sequences related to HIV. In this strategy, $\mathrm{Ag} / \mathrm{SiO} \mathrm{O}_{2}$ core-shell nanoparticle-modified with Raman tags (Rhodamine B) were prepared as SERS probe and MNPs covered with silica shell were functionalized with oligonucleotides related HIV as capture probe. The hybridization reaction was performed between these probes. After the magnetical separation of DNA related to HIV from $3 \mu \mathrm{M}$ solution, the DNA was successfully detected via the SERS probe. In another approach for the detection of genes, Pang et al. [85] developed a SERS sensor based on functionalized $\mathrm{Fe}_{3} \mathrm{O}_{4} @ \mathrm{Ag}$ magnetic nanoparticle for the detection of microRNA (miRNA) in total RNA extract from cancer cells. In this application, unlike the others, MNPs were not only functionalized with the capture agent but also functionalized with the SERS signal reporter. This study has demonstrated the advantage of MNPs which are used to concentrate, capture and purify the target gene with the detection limit of $0.3 \mathrm{fM}$ by using a single hybrid nanostructure. Furthermore, a similar strategy has been applied to the detection of microorganisms [76]. In another example, a seed-mediated strategy was applied to obtain an Ag shell on the surface of MNPs after the $\mathrm{SiO}_{2}$ coating to use the detection of pesticide thiram [86] and the limit of detection was achieved as $1.0 \mathrm{nM}$ for thiram.

The SERS applications of plasmonic nanostructures in different shapes are becoming quite attractive because of increasing the enhancement factor of SERS. As an example, Ruan et al. [69] developed SERS sensor based on triangular silver nanoprisms (AgNPR) and superparamagnetic iron oxide nanoparticles with a function of capture, enrichment, detection, and release for the tumor cells analysis. Firstly, AgNPR was modified with MBA and functionalized with rBSA (i.e., reductive bovine serum albumin) and FA (i.e., folic acid) generating the SERS probe. Then, MNPs were also modified with rBSA and FA generating the capture probe to be used for the capturing, enriching and detecting 
of cancer cells from blood samples. The LOD was obtained as $1 \mathrm{cell} / \mathrm{mL}$ and the results demonstrate that nanoprisms have stronger electromagnetic enhancement compared to nanospheres due to their asymmetric shape. In another example of the SERS applications of plasmonic nanostructures in different shapes, the dual-mode nanoprobes based on SERS and fluorescence detection were developed by using Raman reporter-tagged Au@Ag core-shell nanorods and quantum dots onto the silica nanospheres for IgG detection as mentioned Figure 4 [66]. In this study, LOD was obtained as $0.1 \mathrm{pg} / \mathrm{mL}$ by applying a sandwich assay.

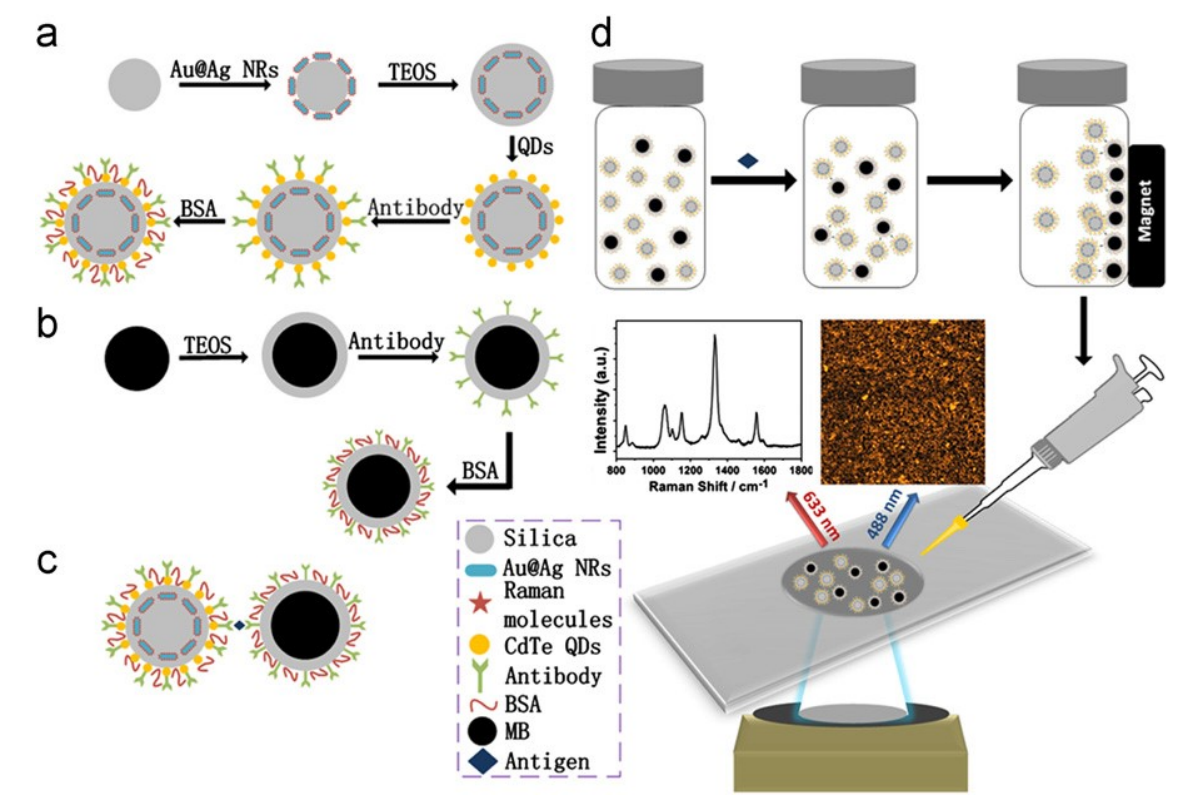

Figure 4. (a) Synthesis and surface functionalization procedure of the dual mode nanoprobe; (b) the synthesis and surface modification procedure of the magnetic beads (MBs); (c) illustration of the structure of the sandwich type nanocomplex formed during the immuno-reaction. For simplicity, only a single nanoprobe, antigen, and MB particle is drawn in the picture; (d) the aqueous phase immunoassay protocol. Reprinted [66] (C) 2013, with permission from Elsevier.

Zong et al. [67] developed a dual-mode sensor system based on colorimetry and magnetic SERS for the detection of telomerase. Au NPs were functionalized with DTNB and telomeric repeat complementary oligonucleotide to produce a bifunctional reporting tag in SERS and colorimetry. MNPs were first coated with silica and Au shell and then modified with telomerase substrate oligonucleotide as capture prob. The coating of Au shell provides easy modification and colorimetric detection via color change after the capturing. LODs of SERS and colorimetry were obtained as 1 tumor cell/mL and 10 tumor cells $/ \mathrm{mL}$, respectively.

As a consequence, MNPs are generally used in two different approaches in SERS applications. In the first one, it is designed as a capture probe for enrichment, purification and separation, and then the detection process by interacting with SERS tag based on the sandwich assay. In the other approach, the magnetic core is modified with SERS reporters such as BMA, DTNB, DP, etc. and plasmonic nanostructures such as Au or Ag shell and used directly as a capture probe and SERS probe. The approaches have advantages in itself as well as the approach being determined according to the analysis to be performed.

\section{Fluorescence Spectroscopy}

Various investigations have been conducted to address the impacts of the dual signal strategy to ameliorate the detection performance of the sensing system $[93,94]$. Different techniques that merge with MNPs have been used to serve as an all-in-one sensing system [95,96]. Among these 
techniques, signal amplification labels relying on the enzyme or DNA labeling, dye labeling, and fluorophore labeling have exhibited great promise thanks to the synchronous properties $[94,97,98]$. Among numerous composite materials, the magneto-fluorescent nanocomposites have a great potential application due to their merits such as optical activity (biolabeling and bioimaging of fluorescent particles) and magnetic field guide opportunity [99-102]. Fluorometric assays have many advantages for biological applications such as higher sensitivity caused by their robust chemical and optical properties. Apart from their intrinsic properties, fluorescent particles have been frequently used for a sensing platform due to their outstanding advantages such as rapid, sensitive and low cost [103-105]. However, there are still some challenges such as an inevitable false signal caused by non-specific adsorption in real samples. Thus, the magnetization of particles was utilized to capture and separated target agents from complex matrices to avoid false signals [106-108]. Furthermore, MNPs can be adopted to utilize as contrast agents for magnetic resonance imaging (MRI) [100,109,110]. Magneto-fluorometric methods for sensing of numerous materials such as heavy metals [111,112], toxins [113], drugs [114,115], pesticide [116], biological materials i.e. DNA [117,118], cell [119,120], bacteria [121], etc. have been investigated. A summary of the different applications of fluorescence-based MNPs is given in Table 3 . 
Table 3. Some examples of fluorescence-based MNPs sensors.

\begin{tabular}{|c|c|c|c|c|c|c|c|c|}
\hline Types of NPs & Capture probe & Size nm & Signal Probe & Size nm & Method & Target & LOD & [R] \\
\hline MNPs@CuNCs & Folate receptor functionalized MNPs & 300 & $\begin{array}{l}\text { Fluorescent copper } \\
\text { nanoclusters }\end{array}$ & 20 & Sandwich assay & $\begin{array}{l}\text { Streptavidin and } \\
\text { biotin }\end{array}$ & $0.47 \mathrm{nM}$ and $3.1 \mathrm{nM}$ & [93] \\
\hline MNPs@FMs & $\begin{array}{l}\text { Monoclonal antibodies (MAbs) } \\
\text { immobilized } \mathrm{Fe}_{3} \mathrm{O}_{4} \text { MNPs }\end{array}$ & 150 & $\begin{array}{l}\text { PAbs functionalized } \\
\text { fluorescent microspheres (FMs) }\end{array}$ & 150 & $\begin{array}{l}\text { Microfluidic biosensor- smartphone } \\
\text { based fluorescent microscopic system }\end{array}$ & $\begin{array}{l}\text { Salmonella } \\
\text { typhimurium }\end{array}$ & $58 \mathrm{CFU} / \mathrm{mL}$ & {$[122$} \\
\hline 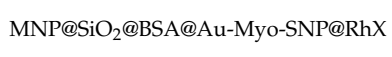 & $\mathrm{Fe}_{3} \mathrm{O}_{4} \mathrm{MNP@SiO2@BSA@Au@antibody}$ & 292 & $\begin{array}{l}\text { SNP@RhX@antibody } \\
\text { conjugates }\end{array}$ & 85 & Sandwich assay & myoglobin & $0.28 \mathrm{ng} / \mathrm{mL}$ & {$[123$} \\
\hline MNPs-aptamer/TRFLNPs-cDNA & $\begin{array}{c}\mathrm{Fe}_{3} \mathrm{O}_{4} \mathrm{MNPs} \text { functionalized with ZEN } \\
\text { aptamers }\end{array}$ & 55 & $\begin{array}{l}\mathrm{NaYF}_{4}: \mathrm{Ce} / \mathrm{Tb} \text { modified } \\
\text { complementary DNA } \\
\text { (TRFLNPs-cDNA) }\end{array}$ & 34 & Sandwich assay & Zearalenone (ZEN) & $0.21 \mathrm{pg} / \mathrm{mL}$ & {$[124$} \\
\hline MNPs@ssDNA-FAM & $\begin{array}{c}\mathrm{Fe}_{3} \mathrm{O}_{4} \text { MNPs functionalized } \\
\text { with ssDNA }\end{array}$ & 50 & carboxyfluorescein (FAM) & - & Sandwich assay & Total mercury $(\mathrm{Hg})$ & $0.49 \mathrm{nM}$ & {$[125$} \\
\hline Aptamer-conjugated FMNPs & $\begin{array}{l}\text { Specific aptamer modified fluorescent } \\
\text { magnetic nanoparticles (FMNPs) }\end{array}$ & 100 & - & - & Smartphone-based detection & $\begin{array}{l}\text { Staphylococcus } \\
\text { aureus }\end{array}$ & $10 \mathrm{CFU} / \mathrm{mL}$ & {$[126$} \\
\hline $\mathrm{CoFe}_{2} \mathrm{O}_{4} @$ dopamine@HSA@PDI-4NH & $\mathrm{CoFe}_{2} \mathrm{O}_{4} @$ dopamine@HSA@PDI-4NH & 190 & PDI- $4 \mathrm{NH}_{2}$ (Perylene diimide) & - & Fluorescence imaging & Cell imaging & - & {$[127$} \\
\hline $\begin{array}{c}\mathrm{Fe}_{3} \mathrm{O}_{4} @ \text { @aptamer 1@ IFN- } \gamma @ \text { @aptamer- } \\
\text { FAMs@dsDNA }\end{array}$ & $\mathrm{Fe}_{3} \mathrm{O}_{4}$-aptamer $1 /$ IFN- $\gamma /$ aptamer & $100-300$ & $\begin{array}{l}\text { carboxyfluorescein modified } \\
\text { aptamer and dsDNA } \\
\text { (FAMs@dsDNA) }\end{array}$ & - & $\begin{array}{l}\text { Aptamer/protein/aptamerpolymer } \\
\text { supersandwich fluorescence sensor }\end{array}$ & $\begin{array}{l}\text { Interferon gamma } \\
\quad(\text { IFN- } \gamma)\end{array}$ & $0.175 \mathrm{fM}$ & {$[128$} \\
\hline $\mathrm{Fe}_{3} \mathrm{O}_{4} @ \mathrm{SiO}_{2}-\mathrm{NH}_{2}$-morin & $\mathrm{Fe}_{3} \mathrm{O}_{4} @ \mathrm{SiO}_{2}-\mathrm{NH}_{2}$ & 78 & Morin & - & Fluorescence titrations & $\mathrm{Cu}^{2+}$ & $7.5 \mathrm{nM}$ & [129] \\
\hline $\mathrm{Fe}_{3} \mathrm{O}_{4} @ \mathrm{SiO}_{2} @ \mathrm{Au} \mathrm{MNPs}$ & $\mathrm{Fe}_{3} \mathrm{O}_{4} @ \mathrm{SiO}_{2} @ \mathrm{Au} \mathrm{MNPs}$ & 11 & BSA-Au NCs & - & $\mathrm{H} 2 \mathrm{O} 2$ quenching & glucose & $3.0 \mu \mathrm{M}$ & {$[130$} \\
\hline $\begin{array}{l}\text { MNP-2nd DNA probe-target DNA-1st } \\
\text { DNA probe-GNP-barcode DNA }\end{array}$ & $\begin{array}{l}\text { Second target specific DNA probe } \\
\text { modified } \mathrm{Fe}_{3} \mathrm{O}_{4} \text { MNPs }\end{array}$ & 45 & $\begin{array}{l}\text { First target-specific DNA probe } \\
1 \text { (1pDNA) and bio-barcode } \\
\text { DNA coated Au NPs (GNP) }\end{array}$ & 23 & Sandwich assay & $\begin{array}{l}\text { Exotoxin A gene } \\
\text { sequence }\end{array}$ & $1.2 \mathrm{ng} / \mathrm{mL}$ & [131] \\
\hline MNPs-PEI-ssDNA & MNPs-PEI-ssDNA & 78 & dye-labeled DNA & - & Sandwich assay & lipopolysaccharide & $35 \mathrm{ng} / \mathrm{mL}$ & [132. \\
\hline
\end{tabular}

MNPs@CuNCs: Magnetic nanoparticles-fluorescent copper nanoclusters; Rhodamine Red-X: RhX; SNP: Silica nanoparticle. 
Liu et al. synthesized magnetic-fluorescent nanoparticles that were able to separate DNA. These research findings have indicated that the adsorption capacity was increased by using this approach. These nanoparticles also allowed to perform an experiment with only a small amount of nanocomposite except the necessity of radioactive probe [98].

According to the work of Cao et al., MNPs and highly fluorescent copper nanoclusters were prepared respectively by following approaches, streptavidin immobilization onto the surface afterward of the co-precipitation method and polymerization by using poly $(\mathrm{T})$ as a template. The primary benefits of this research are that the dual-signal obtained from the supernatant and the re-dispersed precipitate confirmed each other and be integrated in order to result in a solid and quantitative detection [93].

In the case of Kim et al. research, dye-doped silica nanoparticles as fluorescent tagging and MNPs as a concentrating agent were utilized. The nanoparticles mentioned were used for the determination of enrofloxacin by combining with laser-induced fluorescence microscopy. The proposed technique has greatly improved the detection limit when it's compared with conventional methods such as ELISA [133].

A publication by Zarei-Ghobadi et al. has reported the fabrication of a genosensor for detection of target DNA based on the photoluminescence quenching of fluorescent dots in presence of $\mathrm{Fe}_{3} \mathrm{O}_{4}$ MNPs. The described nano(bio)sensor highlights the utilization of MNPs coated by the gold layer which enabled higher surface area as a quencher of fluorescent carbon dots. Also, the proposed sensor system was introduced as a good candidate for biosensing applications due to their advantages such as ease-synthesis, high biocompatibility, cost-effectivity and strong adsorption ability [134].

Another example of fluorescence shell tagging on MNPs was used to distinguish three cancer cell lines with different expression levels. A significant advantage in this study consists of the dual-mode nanoprobe which can be employed not only in the fluorescence measurements but also magnetic resonance-based cancer cell targeting [94].

Wang's group developed a bio-nanocomposite that has two parts i.e. superparamagnetic $\mathrm{Fe}_{3} \mathrm{O}_{4}$ nanoclusters as core and fluorescent dye molecule covalently doped onto silica layers to use an imaging and a photothermal therapy agent. In this contribution, bio-nanocomposite obtained were successfully applied in the specific photothermal therapy of colorectal cancer cells with high stability and reproducibility advantages [107]

Another genomagnetic separation based on fluorescence assay was offered by Liu et al. for the detection of mercury in the canned fish sample. The proposed system was successfully applied for monitoring of trace amounts of mercury even after reused for 6 cycling times [125].

Niazi et al. were also developed a novel magneto fluorescent nanosphere by combining aptamer functionalized $\mathrm{Fe}_{3} \mathrm{O}_{4}$ and $\mathrm{NaYF}_{4}: \mathrm{Ce} / \mathrm{Tb}$ fluorescence nanoparticles for the detection of mycotoxin called zearalenone. Time-resolved fluorescence (TRFL) nanoparticles were labeled with complementary DNA to obtain the signal probe while amine-functionalized MNPs were labeled with zearalenone (ZEN) aptamer to obtain the capture probe. This novel bio-nanocomposite exhibits distinctive features such as stable, specific, convenient and rapid measurements. The schematic protocol for this magneto-fluorescent assay is shown in Figure 5 [124].

Fluorescent chemosensor assay was performed for the detection of target molecules which was based on internal charge transfer. Briefly, in the presence of target molecules interaction between magneto-fluorescent particles and $\mathrm{Cu}^{2+}$ that causes quenching due to the coordination with sensing platform was decreased distinctly because of the decomplexation result with an increase in the fluorescence intensity. The developed chemosensor in this study was successfully used for the monitoring of glutathione oxidized as a template molecule [135].

Another approach to use MNPs in combination with fluorescent structures has been proposed by Wang et al. Major novelty in this research was reported as utilizing not only fluorescent DNA nanotag but also enriched MNPs with DNA for the first time. Among various advantages, such as low non-specific adsorption, ultra-high sensitivity, easy preparation i.e., the proposed technique offers significant promise due to allowing the detection of even a single protein, in that case, human IgG [136]. 


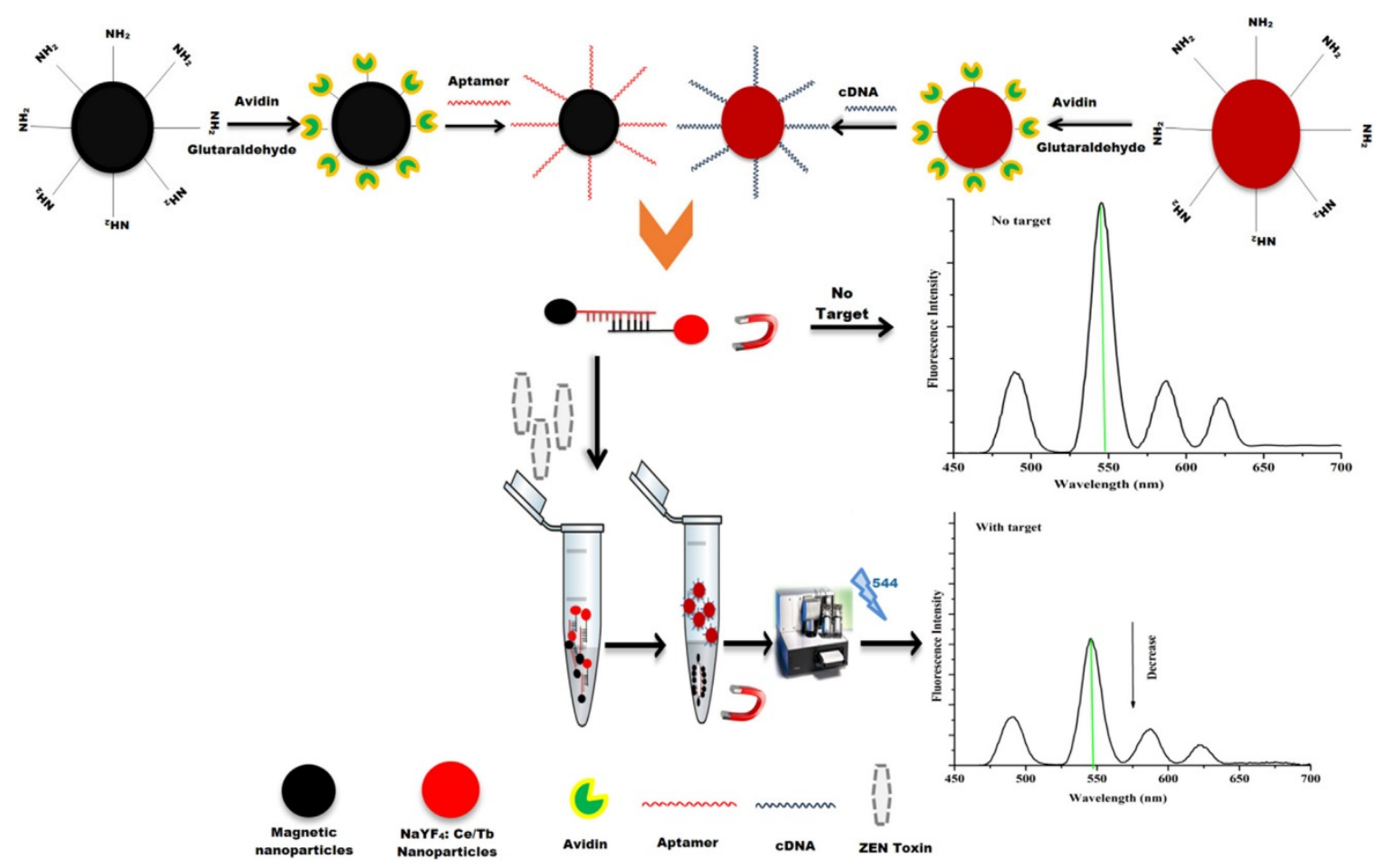

Figure 5. The detection principle based on MNPs as capture probe and fluorescent nanoparticles as a signal probe [124].

Wang and Jiang investigated solvothermal synthesizes of $\mathrm{CePO}_{4}: \mathrm{Tb}, \mathrm{Gd}$ hollow nanospheres which showed significant properties such as peroxidase mimetic activity and magnetic-fluorescent abilities into one nano-entity. The aforementioned properties made the prepared composite nanomaterials as potential applications in biocatalysis and bioimaging [110].

Other promising research was reported localized magnetic field distributions in a microchannel by using nickel powder [137]. They have captured the red fluorescent MNPs with the proposed platform [138-140]. Results have shown a great potential application in chemistry, biology, biomedicine and tissue engineering.

\section{Near Infrared Spectroscopy (NIRS) and Imaging}

Near-infrared spectroscopy (NIRS) based on the measurement of absorption of electromagnetic radiation, including wavelengths of 750 to $2500 \mathrm{~nm}$ is a type of vibration spectroscopy. The absorption bands originate mostly from the vibrations of molecular bonds such as $\mathrm{C}-\mathrm{H}, \mathrm{O}-\mathrm{H}, \mathrm{C}-\mathrm{O}$, and $\mathrm{N}-\mathrm{H}$ within the structure [141]. The Spectra consisting of absorption bands allows the quantitative and qualitative analysis of the molecule being analyzed. However, the NIR radiation can easily penetrate into the body and also NIR radiation is scattered less than UV or visible radiation. Hence, the information based on imaging from the inner body can be obtained by analyzing its spectrum of NIRS [142]. Besides these features, NIRS has important advantages such as being fast and simple, and requiring little sample amount without pre-treatment. There are many applications for the analysis of raw material and product quality in food, pharmaceutical and agricultural industries [141,143,144]. Some applications are summarized in Table 4. In recent years, the new generation NIRS devices developed as functional near-infrared spectroscopy (fNIRS) have been also used for the diagnosis especially in biomedical applications such as neuroimaging, sugar blood, etc. 
Table 4. Some applications of near-infrared spectroscopy (NIRS) sensors based on MNPs.

\begin{tabular}{|c|c|c|c|c|c|c|c|}
\hline Types of NPs* & Size, $\mathrm{nm}$ & MNPs form & NIR agent & Target & Methods & Advantages & [R] \\
\hline CMNPs & 45 & $\mathrm{Fe}_{3} \mathrm{O}_{4}$ & Cy5.5 & Tumor cells & $\begin{array}{c}\text { Specific cancer-targeting and } \\
\text { magnetic resonance/ } \\
\text { near-infrared(MR/NIR) } \\
\text { imaging }\end{array}$ & $\begin{array}{l}\text { Dual imaging, excellent } \\
\text { structural stability with } \\
\text { biocompatible and } \\
\text { biodegradable }\end{array}$ & [145] \\
\hline $\mathrm{Fe}_{3} \mathrm{O}_{4} @ P P y-P E G$ & 89 & $\mathrm{Fe}_{3} \mathrm{O}_{4}$ & $\begin{array}{l}\text { Polypyrrole } \\
\text { (PPy) }\end{array}$ & Tumor cells & $\begin{array}{l}\text { Photothermal therapy, } \\
\text { magnetic targeting }\end{array}$ & $\begin{array}{l}\text { Combination of combined } \\
\text { the Fenton reaction and } \\
\text { photothermal and } \\
\text { magnet-guided } \\
\text { cancer therapy }\end{array}$ & [146] \\
\hline MFG-SiNc 4 & 40 & $\begin{array}{l}\text { Magnetic } \\
\text { graphene }\end{array}$ & $\begin{array}{l}\mathrm{SiNc}_{4} \text { and } \\
\text { fluorescein }\end{array}$ & Tumor cells & $\begin{array}{l}\text { Photodynamic/photothermal } \\
\text { therapeutic }\end{array}$ & $\begin{array}{c}\text { Time and cost effective } \\
\text { treatments with a minimal } \\
\text { therapy dose }\end{array}$ & [147] \\
\hline DOX-Fe $\mathrm{O}_{4} @ \mathrm{PAAP}$ & 170 & $\mathrm{Fe}_{3} \mathrm{O}_{4}$ & $\begin{array}{l}\text { Hydrophobic } \\
\mathrm{Fe}_{3} \mathrm{O}_{4}\end{array}$ & $\begin{array}{l}\text { Doxorubicin } \\
\quad(\mathrm{DOX})\end{array}$ & $\begin{array}{c}\text { In situ drug release and } \\
\text { combined } \\
\text { photothermal-chemotherapy }\end{array}$ & $\begin{array}{l}\text { Fast and effective } \\
\text { thermosensitive } \\
\text { drug delivery }\end{array}$ & [148] \\
\hline CdHgTe@DMF & 100 & $\begin{array}{l}\text { Magnetic } \\
\text { layered } \\
\text { double } \\
\text { hydroxide }\end{array}$ & $\begin{array}{l}\text { Quantum dots } \\
\text { of CdHgTe }\end{array}$ & Tumor cells & $\begin{array}{l}\text { Drug delivery, optical } \\
\text { bioimaging and magnetic } \\
\text { targeted therapy }\end{array}$ & $\begin{array}{l}\text { Slow-release curative effect } \\
\text { and good cell imaging }\end{array}$ & [149] \\
\hline $\begin{array}{l}\mathrm{Fe}_{3} \mathrm{O}_{4} \text {-Aurods- } \mathrm{Fe}_{3} \mathrm{O}_{4} \\
\text { nanodumbbells }\end{array}$ & 70 & $\mathrm{Fe}_{3} \mathrm{O}_{4}$ & $\begin{array}{l}\text { Au Nanorods } \\
\text { (Aurods) }\end{array}$ & $\begin{array}{l}\text { Multiple } \\
\text { pathogens }\end{array}$ & $\begin{array}{l}\text { Detection, magnetic } \\
\text { separation, and photokilling } \\
\text { of multiple pathogens }\end{array}$ & $\begin{array}{l}\text { Tunable nanoprobes for } \\
\text { multiplex detection }\end{array}$ & [36] \\
\hline
\end{tabular}

* CMNPs: PSI-g-C12-PEG-folate cross-linked magnetic nanoparticles; MFG-SiNc4: magnetic and fluorescent graphene (MFG) functionalized with $\mathrm{SiNc}_{4}$; PAAP: poly (acrylamide-co-aniline)-g-PEG; DMF: dextran-magnetic layered double hydroxide-fluorouracil; PEG: Polyethylene glycole.

MNPs are widely used in NIRS due to their superior properties as targeting and MRI agent to improve the resolution and therapy by the development of dual-mode imaging and therapy systems. As an example, Zhou et al. [150] developed the multimodal theranostic platform by using the $\mathrm{Fe}_{3} \mathrm{O}_{4}$ magnetic nanoparticle as an MRI contrast agent and Indocyanine Green (IR820) as an NIR imaging agent. Firstly, $\mathrm{Fe}_{3} \mathrm{O}_{4}$-chitosan quaternary ammonium salt (CSQ-Fe) conjugate was synthesized to increase the stability and biocompatible of MNPs. Then, CSQ-Fe modified with IR820 and fluorescein isothiocyanate (FITC), separately. IR-CSQ-Fe and FITC-CSQ-Fe have similar size distribution and zeta potential and also their behavior in cellular uptake is quite comparable. Therefore, FITC-CSQ-Fe was used to determine the cellular uptake of IR820-CSQ-Fe. As a result, cell viability, long-time stability, MRI imaging, and photodynamic therapy tests indicate that IR-CSQ-Fe can be used as MRI and contrast agent for cancer diagnosis and detection. In another study, Zhou et al. [151] synthesized the $\mathrm{Fe}_{3} \mathrm{O}_{4}$ MNPs modified with NIR dye for sentinel lymph node mapping via the dual-mode imaging probe including MRI and NIR imaging. These conjugates performed better than small conventional dyes. Yang et al. [145] prepared biodegradable and biocompatible polymer-modified MNPs and functionalized with NIR dye Cy5.5 for specific cancer targeting and dual-mode imaging in vivo. Firstly, poly(succinimide) (PSI)-g-C 12 -PEG-folate was synthesized to improve biodegradable and biocompatible characteristics and then modified with $\mathrm{Fe}_{3} \mathrm{O}_{4}$ MNPs and NIR dye Cy5.5 for dual imaging. Consequently, MNPs were coated with a polymer and this hybrid material has an efficient NIR signal, high MRI sensitivity, an active targeting function, and good structural stability. Wu et al. [146] developed a new strategy for cancer imaging and therapy based on a combination of $\mathrm{Fe}_{3} \mathrm{O}_{4}$ MNPs and polypyrole (PPy) in vivo Fenton reaction as illustrated in Figure 6. $\mathrm{Fe}_{3} \mathrm{O}_{4}$ magnetic core used for targeting the tumor site by applying the magnetic field was coated with PPy shell as near-infrared (NIR) light absorber for converting into heat for the photothermal ablation of tumors (PTT) and then modified functionalized with polyethylene glycol. Moreover, PPy coating not only provided PTT but also prevented $\mathrm{Fe}^{2+/ 3+}$ release from $\mathrm{Fe}_{3} \mathrm{O}_{4}$ MNPs. This approach indicated the first time that the releasing of iron ions from $\mathrm{Fe}_{3} \mathrm{O}_{4}$ in acidic medium and the Fenton reaction were enhanced by the photothermal effect. As a result, this hybrid nanoparticle obtained the combination of Fenton reaction and PPy as photothermal therapy provided efficient tumor damage without the effecting of normal organs. In another study, Huang et al. [152] synthesized chlorin e6 (Ce6) as a photosensitizer coated on the surface of $\mathrm{Fe}_{3} \mathrm{O}_{4}$ MNPs for gastric cancer imaging and therapy. As in other NIRS applications, MNPs have been used as targeting and MRI agents in this application and final multifunctional nanocarriers exhibited good water solubility and less cytotoxicity and good biocompatibility with high photodynamic 
efficiency. As a consequence, the synthesized multifunctional nanocarriers performed targeting PDT and dual-mode NIR fluorescence imaging and MRI of gastric cancer tissue in vivo. In another similar study, graphene oxide was modified with ferrocene for targeting and functionalized with fluorescein for NIR fluorescence imaging [147]. After these modifications, the surface of nanoparticles was modified with silicon 2,3-naphthalocyanine bis (trihexylsilyloxide) $\left(\mathrm{SiNc}_{4}\right)$ as a photosensitizer. $\mathrm{SiN}_{\mathrm{C} 4}$ was an ability to use in the photodynamic (PDT) and photothermal (PTT) therapies. This theranostic nanocarrier was used for cost and time-effective treatments with dual-mode imaging and phototherapy of cancer cells by a single light source. Cho et al. [153] designed the injectable nanocarrier based on hydrogel and collagen for drug delivery, phototherapy, and imaging. In this study, the high drug-loading capacity of hydrogel was utilized.

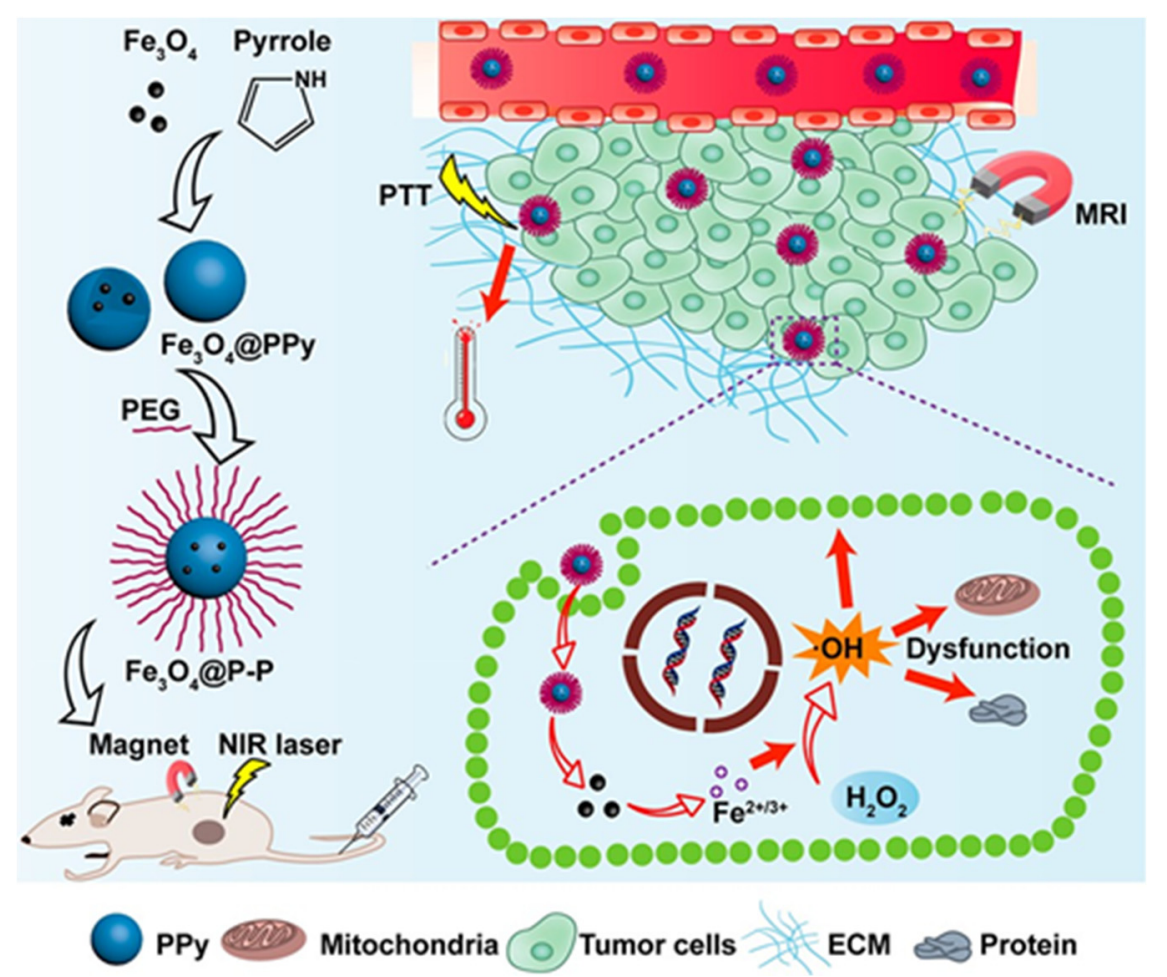

Figure 6. Schematic illustration of the synthetic route of Fe3O4@P-P NPs and the proposed synergistic antitumor mechanism of Fe3O4@P-P NPs. Reprinted with permission from [146]. Copyright American Chemical Society, 2018.

In addition to cell imaging and phototherapy, magnetic nanoparticle-mediated NIRS was used for pathogen detection. As an example, Wang and Irudayaraj [36] developed multifunctional nanoparticles based on gold nanorods and $\mathrm{Fe}_{3} \mathrm{O}_{4}$ MNPs for the simultaneous detection of multiple pathogens in a single sample, based on plasmon absorbance, magnetic separation, and thermal ablation. In this study, the plasmonic properties of gold nanorods were an ability to undertake multiple detections and MNPs were used for targeting, imaging and photothermal therapy.

Due to their small size and motility with the potential of the biomedical applications, microrobots have recently attracted attention. In vivo studies are especially prominent for the diagnosis and treatment of disease. In a study, Lee et al. [154] developed a thermosensitive hydrogel-based soft microrobot for targeting and drug delivery by applying NIR stimuli. The microrobot was mainly fabricated with alginate and NIPAM hydrogel for the thermosensitivity and drug loading and $\mathrm{Fe}_{3} \mathrm{O}_{4}$ MNPs were encapsulated into perfluoroalkoxy (PFA) tube for the targeting with a magnetic field. For drug release, a therapeutic drug, doxorubicin (DOX), was loaded into the microrobot. In this study, the drug delivery with the microrobot was performed efficiently in cancer cell treatment through in vitro Hep3B cell testing by NIR and electromagnetic actuation systems. 
In conclusion, MNPs have been effectively used to develop multifunctional dual imaging and targeting systems for the purpose of drug release, targeting, thermal therapy, and imaging in NIRS applications.

\section{Conclusions and Future Challenges}

In recent years, MNPs have attracted much attention because of their unique properties such as biocompatibility, low toxicity, chemical stability, high surface area, easy synthesis, and modification, etc. to develop the multifunctional nanoparticle-based optical-sensing systems. Studies in this field generally consist of two main steps: (1) easy pre-modification process to improve low toxicity, solubility, and stability; (2) a second modification step with a specific recognition agent for targeting, imaging, diagnosis, separation, purification, and treatment. The most important disadvantage of MNPs is the aggregation and this problem can be overcome by the first modification such as silica or polymer coating, etc. The main disadvantage of optical sensors is the low sensitivity and selectivity of complex matrices such as body fluids, environmental samples, etc. and this problem is largely overcome by using the MNPs with a magnetic field. Moreover, the synthesis and characterization of MNPs need to be improved in (bio) sensing devices. In the future, optical sensors tend to miniaturization, implantability or wearability with high measuring accuracy for the multiple detections in (bio) sensing applications. Therefore, MNPs need to be adapted to such modifications for the integration of this field.

Author Contributions: Conceptualization, writing—review and editing R.Ü., E.S., A.M.; funding acquisition, A.M.

Funding: The ICN2 is funded by the CERCA Programme / Generalitat de Catalunya. The ICN2 is supported by the Severo Ochoa program of the Spanish Ministry of Economy, Industry and Competitiveness (MINECO, grant No. SEV-2017-0706). Financial support was obtained under MINECO project MAT2017-87202-P.

Conflicts of Interest: The authors declare no conflict of interest.

\section{References}

1. Koh, I.; Josephson, L. Magnetic nanoparticle sensors. Sensors (Basel) 2009, 9, 8130-8145. [CrossRef]

2. Nikiforov, V.N.; Filinova, E.Y. Biomedical Applications of Magnetic Nanoparticles. In Magnetic Nanoparticles; Gubin, S.P., Ed.; Wiley-VCH Verlag GmbH \& Co. KGaA: Weinheim, Germany, 2009; pp. 393-444.

3. Mou, X.; Ali, Z.; Li, S.; He, N. Applications of Magnetic Nanoparticles in Targeted Drug Delivery System. J. Nanosci. Nanotechnol. 2015, 15, 54-62. [CrossRef]

4. Bao, Y.; Wen, T.; Samia, A.C.; Khandhar, A.; Krishnan, K.M. Magnetic Nanoparticles: Material Engineering and Emerging Applications in Lithography and Biomedicine. J. Mater. Sci. 2016, 51, 513-553. [CrossRef]

5. Rocha-Santos, T.A.P. Sensors and biosensors based on magnetic nanoparticles. Trends Anal. Chem. 2014, 62, 28-36. [CrossRef]

6. Colombo, M.; Carregal-Romero, S.; Casula, M.F.; Gutierrez, L.; Morales, M.P.; Bohm, I.B.; Heverhagen, J.T.; Prosperi, D.; Parak, W.J. Biological applications of magnetic nanoparticles. Chem. Soc. Rev. 2012, 41, 4306-4334. [CrossRef] [PubMed]

7. Mejías, R.; Pérez-Yagüe, S.; Roca, A.G.; Pérez, N.; Villanueva, Á.; Cañete, M.; Mañes, S.; Ruiz-Cabello, J.; Benito, M.; Labarta, A. Liver and brain imaging through dimercaptosuccinic acid-coated iron oxide nanoparticles. Nanomedicine 2010, 5, 397-408. [CrossRef] [PubMed]

8. Anbarasu, M.; Anandan, M.; Chinnasamy, E.; Gopinath, V.; Balamurugan, K. Synthesis and characterization of polyethylene glycol (PEG) coated Fe3O4 nanoparticles by chemical co-precipitation method for biomedical applications. Spectrochim. Acta A Mol. Biomol. Spectrosc. 2015, 135, 536-539. [CrossRef] [PubMed]

9. Figuerola, A.; Di Corato, R.; Manna, L.; Pellegrino, T. From iron oxide nanoparticles towards advanced iron-based inorganic materials designed for biomedical applications. Pharmacol. Res. 2010, 62, $126-143$. [CrossRef] [PubMed]

10. Li, X.; Wei, J.; Aifantis, K.E.; Fan, Y.; Feng, Q.; Cui, F.Z.; Watari, F. Current investigations into magnetic nanoparticles for biomedical applications. J. Biomed. Mater. Res. A 2016, 104, 1285-1296. [CrossRef] 
11. Chen, Q.; Rondinone, A.J.; Chakoumakos, B.C.; Zhang, Z.J. Synthesis of superparamagnetic MgFe2O4 nanoparticles by coprecipitation. J. Magn. Magn. Mater. 1999, 194, 1-7. [CrossRef]

12. Puntes, V.F.; Krishnan, K.M.; Alivisatos, A.P. Colloidal nanocrystal shape and size control: The case of cobalt. Science 2001, 291, 2115-2117. [CrossRef] [PubMed]

13. Weller, D.; Moser, A. Thermal effect limits in ultrahigh-density magnetic recording. IEEE Trans. Magn. 1999, 35, 4423-4439. [CrossRef]

14. Andres, R.P.; Bein, T.; Dorogi, M.; Feng, S.; Henderson, J.I.; Kubiak, C.P.; Mahoney, W.; Osifchin, R.G.; Reifenberger, R. "Coulomb Staircase” at Room Temperature in a Self-Assembled Molecular Nanostructure. Science 1996, 272, 1323-1325. [CrossRef] [PubMed]

15. Sun, S.; Murray, C.B.; Weller, D.; Folks, L.; Moser, A. Monodisperse FePt nanoparticles and ferromagnetic FePt nanocrystal superlattices. Science 2000, 287, 1989-1992. [CrossRef] [PubMed]

16. Chen, X.J.; Zhu, J.W.; Chen, Z.X.; Xu, C.B.; Wang, Y.; Yao, C. A novel bienzyme glucose biosensor based on three-layer Au-Fe3O4@SiO2 magnetic nanocomposite. Sens. Actuators B Chem. 2011, 159, 220-228. [CrossRef]

17. Baghayeri, M.; Nazarzadeh Zare, E.; Mansour Lakouraj, M. A simple hydrogen peroxide biosensor based on a novel electro-magnetic poly (p-phenylenediamine) @ Fe3O4 nanocomposite. Biosens. Bioelectron. 2014, 55, 259-265. [CrossRef]

18. Baghayeri, M.; Veisi, H.; Ghanei-Motlagh, M. Amperometric glucose biosensor based on immobilization of glucose oxidase on a magnetic glassy carbon electrode modified with a novel magnetic nanocomposite. Sens. Actuators B Chem. 2017, 249, 321-330. [CrossRef]

19. Zhao, Y.; Zhang, W.; Lin, Y.; Du, D. The vital function of Fe3O4@Au nanocomposites for hydrolase biosensor design and its application in detection of methyl parathion. Nanoscale 2013, 5, 1121-1126. [CrossRef]

20. Liu, J.; Qiao, S.Z.; Hu, Q.H.; Lu, G.Q. Magnetic nanocomposites with mesoporous structures: Synthesis and applications. Small 2011, 7, 425-443. [CrossRef]

21. Corma, A. From microporous to mesoporous molecular sieve materials and their use in catalysis. Chem. Rev. 1997, 97, 2373-2419. [CrossRef]

22. Lu, A.H.; Schuth, F. Nanocasting: A versatile strategy for creating nanostructured porous materials. Adv. Mater. 2006, 18, 1793-1805. [CrossRef]

23. Ying, J.Y.; Mehnert, C.P.; Wong, M.S. Synthesis and applications of supramolecular-templated mesoporous materials. Angew. Chem. Int. Ed. 1999, 38, 56-77. [CrossRef]

24. Kudr, J.; Haddad, Y.; Richtera, L.; Heger, Z.; Cernak, M.; Adam, V.; Zitka, O. Magnetic Nanoparticles: From Design and Synthesis to Real World Applications. Nanomaterials (Basel) 2017, 7, 243. [CrossRef] [PubMed]

25. Leena, M.; Gomaa, H.; Ragab, D.; Zhu, J. Magnetic nanoparticles for environmental and biomedical applications. Particuology 2017, 30,1-14.

26. Willard, M.A.; Kurihara, L.K.; Carpenter, E.E.; Calvin, S.; Harris, V.G. Chemically prepared magnetic nanoparticles. Int. Mater. Rev. 2004, 49, 125-170. [CrossRef]

27. Reddy, L.H.; Arias, J.L.; Nicolas, J.; Couvreur, P. Magnetic nanoparticles: design and characterization, toxicity and biocompatibility, pharmaceutical and biomedical applications. Chem. Rev. 2012, 112, 5818-5878. [CrossRef]

28. Kango, S.; Kalia, S.; Celli, A.; Njuguna, J.; Habibi, Y.; Kumar, R. Surface modification of inorganic nanoparticles for development of organic-inorganic nanocomposites-A review. Prog. Polymer Sci. 2013, 38, 1232-1261. [CrossRef]

29. Mahmoudi, M.; Sant, S.; Wang, B.; Laurent, S.; Sen, T. Superparamagnetic iron oxide nanoparticles (SPIONs): development, surface modification and applications in chemotherapy. Adv. Drug Deliv. Rev. 2011, 63, $24-46$. [CrossRef]

30. da Silva, B.F.; Pérez, S.; Gardinalli, P.; Singhal, R.; Mozeto, A.A.; Barceló, D. Analytical chemistry of metallic nanoparticles in natural environments. Trends Anal. Chem. 2011, 30, 528-540. [CrossRef]

31. Madkour, L.H. Biogenic-biosynthesis metallic nanoparticles (MNPs) for pharmacological, biomedical and environmental nanobiotechnological applications. Chron. Pharm. Sci. J. 2018, 2, 384-444.

32. Coulet, P.R. What is a Biosensor. In Biosensor Principles and Applications; Coulet, P.R., Blum, L.J., Eds.; CRC Press: New York, NY, USA, 1991; pp. 1-8.

33. Suvarnaphaet, P.; Pechprasarn, S. Graphene-Based Materials for Biosensors: A Review. Sensors (Basel) 2017, 17, 2161. [CrossRef] [PubMed] 
34. Tereshchenko, A.; Bechelany, M.; Viter, R.; Khranovskyy, V.; Smyntyna, V.; Starodub, N.; Yakimova, R. Optical biosensors based on $\mathrm{ZnO}$ nanostructures: advantages and perspectives. A review. Sens. Actuators B Chem. 2016, 229, 664-677. [CrossRef]

35. Fan, X.; White, I.M.; Shopova, S.I.; Zhu, H.; Suter, J.D.; Sun, Y. Sensitive optical biosensors for unlabeled targets: a review. Anal. Chim. Acta 2008, 620, 8-26. [CrossRef] [PubMed]

36. Wang, C.; Irudayaraj, J. Multifunctional magnetic-optical nanoparticle probes for simultaneous detection, separation, and thermal ablation of multiple pathogens. Small 2010, 6, 283-289. [CrossRef]

37. Englebienne, P.; Van Hoonacker, A.; Verhas, M. Surface plasmon resonance: principles, methods and applications in biomedical sciences. Spectrosc. Int. J. 2003, 17, 255-273. [CrossRef]

38. Tudos, A.J.; Schasfoort, R.B.M. Introduction to Surface Plasmon Resonance. In Handbook of Surface Plasmon Resonance; Royal Society of Chemistry: London, UK, 2008; pp. 1-14. [CrossRef]

39. Van Der Merwe, P.A. Surface plasmon resonance. In Protein-Ligand Interactions: Hydrodynamics Calorimetry; Oxford University Press: Oxford, UK, 2001; Volume 1, pp. 137-170.

40. Olaru, A.; Bala, C.; Jaffrezic-Renault, N.; Aboul-Enein, H.Y. Surface plasmon resonance (SPR) biosensors in pharmaceutical analysis. Crit. Rev. Anal. Chem. 2015, 45, 97-105. [CrossRef]

41. Nguyen, H.H.; Park, J.; Kang, S.; Kim, M. Surface plasmon resonance: A versatile technique for biosensor applications. Sensors (Basel) 2015, 15, 10481-10510. [CrossRef]

42. Yang, D.; Ma, J.; Peng, M.; Zhang, Q.; Luo, Y.; Hui, W.; Jin, T.; Cui, Y. Building nanoSPR biosensor systems based on gold magnetic composite nanoparticles. J. Nanosci. Nanotechnol. 2013, 13, 5485-5492. [CrossRef]

43. Liu, X.; Li, L.; Liu, Y.Q.; Shi, X.B.; Li, W.J.; Yang, Y.; Mao, L.G. Ultrasensitive detection of deltamethrin by immune magnetic nanoparticles separation coupled with surface plasmon resonance sensor. Biosens. Bioelectron. 2014, 59, 328-334. [CrossRef]

44. Lee, J.R.; Bechstein, D.J.; Ooi, C.C.; Patel, A.; Gaster, R.S.; Ng, E.; Gonzalez, L.C.; Wang, S.X. Magneto-nanosensor platform for probing low-affinity protein-protein interactions and identification of a low-affinity PD-L1/PD-L2 interaction. Nat. Commun. 2016, 7, 12220. [CrossRef]

45. Jia, Y.T.; Peng, Y.; Bai, J.L.; Zhang, X.H.; Cui, Y.G.; Ning, B.A.; Cui, J.S.; Gao, Z.X. Magnetic nanoparticle enhanced surface plasmon resonance sensor for estradiol analysis. Sens. Actuators B Chem. 2018, 254, 629-635. [CrossRef]

46. Lou, Z.; Han, H.; Zhou, M.; Wan, J.; Sun, Q.; Zhou, X.; Gu, N. Fabrication of Magnetic Conjugation Clusters via Intermolecular Assembling for Ultrasensitive Surface Plasmon Resonance (SPR) Detection in a Wide Range of Concentrations. Anal. Chem. 2017, 89, 13472-13479. [CrossRef] [PubMed]

47. Lee, K.S.; Lee, M.; Byun, K.M.; Lee, I.S. Surface plasmon resonance biosensing based on target-responsive mobility switch of magnetic nanoparticles under magnetic fields. J. Mater. Chem. 2011, 21, 5156-5162. [CrossRef]

48. Li, S.; Wu, Q.; Ma, P.; Zhang, Y.; Song, D.; Wang, X.; Sun, Y. A sensitive SPR biosensor based on hollow gold nanospheres and improved sandwich assay with PDA-Ag@Fe3O4/rGO. Talanta 2018, 180, $156-161$. [CrossRef] [PubMed]

49. Chen, H.X.; Qi, F.J.; Zhou, H.; Jia, S.S.; Gao, Y.M.; Koh, K.; Yin, Y.M. Fe3O4@Au nanoparticles as a means of signal enhancement in surface plasmon resonance spectroscopy for thrombin detection. Sens. Actuators B Chem. 2015, 212, 505-511. [CrossRef]

50. Ekariyani, N.Y.; Wardani, D.P.; Suharyadi, E.; Daryono, B.S.; Abraha, K. The use of Fe3O4 magnetic nanoparticles as the active layer to detect plant's DNA with surface plasmon resonance (SPR) based biosensor. In Proceedings of the 1st International Conference on Science and Technology, Yogyakarta, Indonesia, 11-13 November 2015; p. 150016.

51. Liu, X.; Hu, Y.X.; Zheng, S.; Liu, Y.; He, Z.; Luo, F. Surface plasmon resonance immunosensor for fast, highly sensitive, and in situ detection of the magnetic nanoparticles-enriched Salmonella enteritidis. Sens. Actuators B Chem. 2016, 230, 191-198. [CrossRef]

52. Zou, F.; Wang, X.X.; Qi, F.J.; Kohn, K.; Lee, J.; Zhou, H.J.; Chen, H.X. Magneto-plamonic nanoparticles enhanced surface plasmon resonance TB sensor based on recombinant gold binding antibody. Sens. Actuators B Chem. 2017, 250, 356-363. [CrossRef]

53. Wu, Q.; Sun, Y.; Zhang, D.; Li, S.; Wang, X.; Song, D. Magnetic field-assisted SPR biosensor based on carboxyl-functionalized graphene oxide sensing film and Fe3O4-hollow gold nanohybrids probe. Biosens. Bioelectron. 2016, 86, 95-101. [CrossRef] 
54. Wu, Q.; Sun, Y.; Zhang, D.; Li, S.; Zhang, Y.; Ma, P.; Yu, Y.; Wang, X.; Song, D. Ultrasensitive magnetic field-assisted surface plasmon resonance immunoassay for human cardiac troponin I. Biosens. Bioelectron. 2017, 96, 288-293. [CrossRef]

55. Ying, Y.; Zhao, Y.; Lv, R.-Q.; Hu, H.-F. Magnetic field measurement using surface plasmon resonance sensing technology combined with magnetic fluid photonic crystal. IEEE Trans. Instrum. Meas. 2015, 65, 170-176. [CrossRef]

56. Reiner, A.T.; Ferrer, N.G.; Venugopalan, P.; Lai, R.C.; Lim, S.K.; Dostalek, J. Magnetic nanoparticle-enhanced surface plasmon resonance biosensor for extracellular vesicle analysis. Analyst 2017, 142, 3913-3921. [CrossRef] [PubMed]

57. Yuan, C.; Lou, Z.; Wang, W.; Yang, L.; Li, Y. Synthesis of Fe(3)C@C from Pyrolysis of Fe(3)O(4)-Lignin Clusters and Its Application for Quick and Sensitive Detection of $\operatorname{PrP}(\mathrm{Sc})$ through a Sandwich SPR Detection Assay. Int. J. Mol. Sci. 2019, 20, 741. [CrossRef] [PubMed]

58. Nurrohman, D.; Oktivina, M.; Suharyadi, E.; Suyono, E.; Abraha, K. Monitoring Microalgae Population Growth by using Fe3O4 Nanoparticles-based Surface Plasmon Resonance (SPR) Biosensor. In Proceedings of the IOP Conference Series: Materials Science and Engineering, Universitas Negeri Malang, Malang, Indonesia, 27-28 September 2016; p. 012077.

59. Pal, M.K.; Rashid, M.; Bisht, M. Multiplexed magnetic nanoparticle-antibody conjugates (MNPs-ABS) based prognostic detection of ovarian cancer biomarkers, CA-125, $\beta-2 \mathrm{M}$ and ApoA1 using fluorescence spectroscopy with comparison of surface plasmon resonance (SPR) analysis. Biosens. Bioelectron. 2015, 73, 146-152. [CrossRef] [PubMed]

60. Campion, A.; Kambhampati, P. Surface-enhanced Raman scattering. Chem. Soc. Rev. 1998, 27, $241-250$. [CrossRef]

61. Stiles, P.L.; Dieringer, J.A.; Shah, N.C.; Van Duyne, R.P. Surface-enhanced Raman spectroscopy. Annu. Rev. Anal. Chem. (Palo Alto Calif.) 2008, 1, 601-626. [CrossRef]

62. Sharma, B.; Frontiera, R.R.; Henry, A.I.; Ringe, E.; Van Duyne, R.P. SERS: Materials, applications, and the future. Mater. Today 2012, 15, 16-25. [CrossRef]

63. Pilot, R.; Signorini, R.; Durante, C.; Orian, L.; Bhamidipati, M.; Fabris, L. A Review on Surface-Enhanced Raman Scattering. Biosensors (Basel) 2019, 9, 57. [CrossRef]

64. Fan, M.; Andrade, G.F.; Brolo, A.G. A review on the fabrication of substrates for surface enhanced Raman spectroscopy and their applications in analytical chemistry. Anal. Chim. Acta 2011,693, 7-25. [CrossRef]

65. Zengin, A.; Tamer, U.; Caykara, T. A SERS-based sandwich assay for ultrasensitive and selective detection of Alzheimer's tau protein. Biomacromolecules 2013, 14, 3001-3009. [CrossRef]

66. Zong, S.; Wang, Z.; Zhang, R.; Wang, C.; Xu, S.; Cui, Y. A multiplex and straightforward aqueous phase immunoassay protocol through the combination of SERS-fluorescence dual mode nanoprobes and magnetic nanobeads. Biosens. Bioelectron. 2013, 41,745-751. [CrossRef]

67. Zong, S.; Wang, Z.; Chen, H.; Hu, G.; Liu, M.; Chen, P.; Cui, Y. Colorimetry and SERS dual-mode detection of telomerase activity: combining rapid screening with high sensitivity. Nanoscale 2014, 6, 1808-1816. [CrossRef] [PubMed]

68. Mo, A.H.; Landon, P.B.; Gomez, K.S.; Kang, H.; Lee, J.; Zhang, C.; Janetanakit, W.; Sant, V.; Lu, T.; Colburn, D.A.; et al. Magnetically-responsive silica-gold nanobowls for targeted delivery and SERS-based sensing. Nanoscale 2016, 8, 11840-11850. [CrossRef] [PubMed]

69. Ruan, H.M.; Wu, X.X.; Yang, C.C.; Li, Z.H.; Xia, Y.Z.; Xue, T.; Shen, Z.Y.; Wu, A.G. A Supersensitive CTC Analysis System Based on Triangular Silver Nanoprisms and SPION with Function of Capture, Enrichment, Detection, and Release. ACS Biomater. Sci. Eng. 2018, 4, 1073-1082. [CrossRef]

70. Kim, H.M.; Kim, D.M.; Jeong, C.; Park, S.Y.; Cha, M.G.; Ha, Y.; Jang, D.; Kyeong, S.; Pham, X.H.; Hahm, E.; et al. Assembly of Plasmonic and Magnetic Nanoparticles with Fluorescent Silica Shell Layer for Tri-functional SERS-Magnetic-Fluorescence Probes and Its Bioapplications. Sci. Rep. 2018, 8, 13938. [CrossRef]

71. Chen, L.; Hong, W.; Guo, Z.; Sa, Y.; Wang, X.; Jung, Y.M.; Zhao, B. Magnetic assistance highly sensitive protein assay based on surface-enhanced resonance Raman scattering. J. Colloid Interface Sci. 2012, 368, 282-286. [CrossRef]

72. He, D.; Wu, Z.; Cui, B.; Jin, Z. A novel SERS-based aptasensor for ultrasensitive sensing of microcystin-LR. Food Chem. 2019, 278, 197-202. [CrossRef] 
73. Hwang, H.; Kim, S.H.; Yang, S.M. Microfluidic fabrication of SERS-active microspheres for molecular detection. Lab Chip 2011, 11, 87-92. [CrossRef]

74. Yu, S.; Liu, Z.; Wang, W.; Jin, L.; Xu, W.; Wu, Y. Disperse magnetic solid phase microextraction and surface enhanced Raman scattering (Dis-MSPME-SERS) for the rapid detection of trace illegally chemicals. Talanta 2018, 178, 498-506. [CrossRef]

75. Hardiansyah, A.; Chen, A.-Y.; Liao, H.-L.; Yang, M.-C.; Liu, T.-Y.; Chan, T.-Y.; Tsou, H.-M.; Kuo, C.-Y.; Wang, J.-K.; Wang, Y.-L. Core-shell of FePt@SiO2-Au magnetic nanoparticles for rapid SERS detection. Nanoscale Res. Lett. 2015, 10, 412. [CrossRef]

76. Wang, C.; Gu, B.; Liu, Q.; Pang, Y.; Xiao, R.; Wang, S. Combined use of vancomycin-modified Ag-coated magnetic nanoparticles and secondary enhanced nanoparticles for rapid surface-enhanced Raman scattering detection of bacteria. Int. J. Nanomed. 2018, 13, 1159-1178. [CrossRef]

77. Chattopadhyay, S.; Sabharwal, P.K.; Jain, S.; Kaur, A.; Singh, H. Functionalized polymeric magnetic nanoparticle assisted SERS immunosensor for the sensitive detection of S. typhimurium. Anal. Chim. Acta 2019, 1067, 98-106. [CrossRef] [PubMed]

78. Kim, K.; Choi, J.Y.; Lee, H.B.; Shin, K.S. Silanization of Ag-deposited magnetite particles: an efficient route to fabricate magnetic nanoparticle-based Raman barcode materials. ACS Appl. Mater. Interfaces 2010, 2, 1872-1878. [CrossRef]

79. Yang, K.; Hu, Y.; Dong, N. A novel biosensor based on competitive SERS immunoassay and magnetic separation for accurate and sensitive detection of chloramphenicol. Biosens. Bioelectron. 2016, 80, 373-377. [CrossRef] [PubMed]

80. Yu, S.; Liu, Z.; Li, H.; Zhang, J.; Yuan, X.X.; Jia, X.; Wu, Y. Combination of a graphene SERS substrate and magnetic solid phase micro-extraction used for the rapid detection of trace illegal additives. Analyst 2018, 143, 883-890. [CrossRef]

81. Yang, K.; Hu, Y.; Dong, N.; Zhu, G.; Zhu, T.; Jiang, N. A novel SERS-based magnetic aptasensor for prostate specific antigen assay with high sensitivity. Biosens. Bioelectron. 2017, 94, 286-291. [CrossRef]

82. Neng, J.; Harpster, M.H.; Wilson, W.C.; Johnson, P.A. Surface-enhanced Raman scattering (SERS) detection of multiple viral antigens using magnetic capture of SERS-active nanoparticles. Biosens. Bioelectron. 2013, 41, 316-321. [CrossRef]

83. Alula, M.T.; Lemmens, P.; Bo, L.; Wulferding, D.; Yang, J.; Spende, H. Preparation of silver nanoparticles coated $\mathrm{ZnO} / \mathrm{Fe} 3 \mathrm{O} 4$ composites using chemical reduction method for sensitive detection of uric acid via surface-enhanced Raman spectroscopy. Anal. Chim. Acta 2019, 1073, 62-71. [CrossRef]

84. Liang, Y.; Gong, J.L.; Huang, Y.; Zheng, Y.; Jiang, J.H.; Shen, G.L.; Yu, R.Q. Biocompatible core-shell nanoparticle-based surface-enhanced Raman scattering probes for detection of DNA related to HIV gene using silica-coated magnetic nanoparticles as separation tools. Talanta 2007, 72, 443-449. [CrossRef]

85. Pang, Y.F.; Wang, C.W.; Wang, J.; Sun, Z.W.; Xiao, R.; Wang, S.Q. Fe3O4@Ag magnetic nanoparticles for microRNA capture and duplex-specific nuclease signal amplification based SERS detection in cancer cells. Biosens. Bioelectron. 2016, 79, 574-580. [CrossRef]

86. Song, J.; Chen, Z.P.; Jin, J.W.; Chen, Y.; Yu, R.Q. Quantitative surface-enhanced Raman spectroscopy based on the combination of magnetic nanoparticles with an advanced chemometric model. Chemom. Intell. Lab. Syst. 2014, 135, 31-36. [CrossRef]

87. Zengin, A.; Tamer, U.; Caykara, T. Extremely sensitive sandwich assay of kanamycin using surface-enhanced Raman scattering of 2-mercaptobenzothiazole labeled gold@silver nanoparticles. Anal. Chim. Acta 2014, 817, 33-41. [CrossRef] [PubMed]

88. Hou, X.M.; Zhang, X.L.; Chen, S.T.; Kang, H.Z.; Tan, W.H. Facile synthesis of Ni/Au, Ni/Ag hybrid magnetic nanoparticles: New active substrates for surface enhanced Raman scattering. Colloids Surf. A Physicochem. Eng. Asp. 2012, 403, 148-154. [CrossRef]

89. Hassanain, W.A.; Izake, E.L.; Schmidt, M.S.; Ayoko, G.A. Gold nanomaterials for the selective capturing and SERS diagnosis of toxins in aqueous and biological fluids. Biosens. Bioelectron. 2017, 91, 664-672. [CrossRef] [PubMed]

90. Qu, H.; Lai, Y.; Niu, D.; Sun, S. Surface-enhanced Raman scattering from magneto-metal nanoparticle assemblies. Anal. Chim. Acta 2013, 763, 38-42. [CrossRef] [PubMed] 
91. Kim, M.; Ko, S.M.; Chungyeon, L.; Son, J.; Kim, J.; Kim, J.-M.; Nam, J.-M. Hierarchic Interfacial Nanocube Assembly for Sensitive, Selective and Quantitative DNA Detection with Surface-Enhanced Raman Scattering. Anal. Chem. 2019. [CrossRef]

92. Li, D.; Jiang, L.; Piper, J.A.; Maksymov, I.S.; Greentree, A.D.; Wang, E.; Wang, Y. Sensitive and Multiplexed SERS Nanotags for the Detection of Cytokines Secreted by Lymphoma. ACS Sens. 2019, 4, 2507-2514. [CrossRef]

93. Cao, J.; Wang, W.; Bo, B.; Mao, X.; Wang, K.; Zhu, X. A dual-signal strategy for the solid detection of both small molecules and proteins based on magnetic separation and highly fluorescent copper nanoclusters. Biosens. Bioelectron. 2017, 90, 534-541. [CrossRef]

94. Qin, J.; Li, K.; Peng, C.; Li, X.; Lin, J.; Ye, K.; Yang, X.; Xie, Q.; Shen, Z.; Jin, Y.; et al. MRI of iron oxide nanoparticle-labeled ADSCs in a model of hindlimb ischemia. Biomaterials 2013, 34, 4914-4925. [CrossRef]

95. Mahmoudi, M.; Shokrgozar, M.A. Multifunctional stable fluorescent magnetic nanoparticles. Chem. Commun. (Camb.) 2012, 48, 3957-3959. [CrossRef]

96. Ebrahiminezhad, A.; Ghasemi, Y.; Rasoul-Amini, S.; Barar, J.; Davaran, S. Preparation of novel magnetic fluorescent nanoparticles using amino acids. Colloids Surf. B Biointerfaces 2013, 102, 534-539. [CrossRef]

97. Lee, H.U.; Jung, D.U.; Lee, J.H.; Song, Y.S.; Park, C.; Kim, S.W. Detection of glyphosate by quantitative analysis of fluorescence and single DNA using DNA-labeled fluorescent magnetic core-shell nanoparticles. Sens. Actuators B Chem. 2013, 177, 879-886. [CrossRef]

98. Liu, C.H.; Sahoo, S.L.; Tsao, M.H. Acridine orange coated magnetic nanoparticles for nucleus labeling and DNA adsorption. Colloids Surf. B Biointerfaces 2014, 115, 150-156. [CrossRef] [PubMed]

99. Chen, O.; Riedemann, L.; Etoc, F.; Herrmann, H.; Coppey, M.; Barch, M.; Farrar, C.T.; Zhao, J.; Bruns, O.T.; Wei, H.; et al. Magneto-fluorescent core-shell supernanoparticles. Nat. Commun. 2014, 5, 5093. [CrossRef] [PubMed]

100. Wei, Z.; Wu, Y.; Zhao, Y.; Mi, L.; Wang, J.; Wang, J.; Zhao, J.; Wang, L.; Liu, A.; Li, Y.; et al. Multifunctional nanoprobe for cancer cell targeting and simultaneous fluorescence/magnetic resonance imaging. Anal. Chim. Acta 2016, 938, 156-164. [CrossRef]

101. Ruan, J.; Ji, J.; Song, H.; Qian, Q.; Wang, K.; Wang, C.; Cui, D. Fluorescent magnetic nanoparticle-labeled mesenchymal stem cells for targeted imaging and hyperthermia therapy of in vivo gastric cancer. Nanoscale Res. Lett. 2012, 7, 309. [CrossRef]

102. Icten, O.; Kose, D.A.; Matissek, S.J.; Misurelli, J.A.; Elsawa, S.F.; Hosmane, N.S.; Zumreoglu-Karan, B. Gadolinium borate and iron oxide bioconjugates: Nanocomposites of next generation with multifunctional applications. Mater. Sci. Eng. C 2018, 92, 317-328. [CrossRef]

103. Syed, M.A. Advances in nanodiagnostic techniques for microbial agents. Biosens. Bioelectron. 2014, 51, 391-400. [CrossRef]

104. Bhaisare, M.L.; Gedda, G.; Khan, M.S.; Wu, H.F. Fluorimetric detection of pathogenic bacteria using magnetic carbon dots. Anal. Chim. Acta 2016, 920, 63-71. [CrossRef]

105. Wu, Z.; Xu, E.; Chughtai, M.F.J.; Jin, Z.; Irudayaraj, J. Highly sensitive fluorescence sensing of zearalenone using a novel aptasensor based on upconverting nanoparticles. Food Chem. 2017, 230, 673-680. [CrossRef]

106. Clemente, C.S.; Ribeiro, V.G.P.; Sousa, J.E.A.; Maia, F.J.N.; Barreto, A.C.H.; Andrade, N.F.; Denardin, J.C.; Mele, G.; Carbone, L.; Mazzetto, S.E.; et al. Porphyrin synthesized from cashew nut shell liquid as part of a novel superparamagnetic fluorescence nanosystem. J. Nanopart. Res. 2013, 15, 1739. [CrossRef]

107. Wang, F.; Xu, L.; Zhang, Y.; Petrenko, V.A.; Liu, A. An efficient strategy to synthesize a multifunctional ferroferric oxide core@ dye/SiO 2@ Au shell nanocomposite and its targeted tumor theranostics. J. Mater. Chem. B 2017, 5, 8209-8218. [CrossRef]

108. Myklatun, A.; Cappetta, M.; Winklhofer, M.; Ntziachristos, V.; Westmeyer, G.G. Microfluidic sorting of intrinsically magnetic cells under visual control. Sci. Rep. 2017, 7, 6942. [CrossRef]

109. Yin, M.; Li, Z.; Liu, Z.; Ren, J.; Yang, X.; Qu, X. Photosensitizer-incorporated G-quadruplex DNA-functionalized magnetofluorescent nanoparticles for targeted magnetic resonance/fluorescence multimodal imaging and subsequent photodynamic therapy of cancer. Chem. Commun. (Camb.) 2012, 48, 6556-6558. [CrossRef] [PubMed]

110. Wang, W.; Jiang, X.; Chen, K. CePO 4: Tb, Gd hollow nanospheres as peroxidase mimic and magnetic-fluorescent imaging agent. Chem. Commun. 2012, 48, 6839-6841. [CrossRef] [PubMed] 
111. Zheng, J.; Nie, Y.; Hu, Y.; Li, J.; Li, Y.; Jiang, Y.; Yang, R. Time-resolved fluorescent detection of Hg $2+$ in a complex environment by conjugating magnetic nanoparticles with a triple-helix molecular switch. Chem. Commun. 2013, 49, 6915-6917. [CrossRef]

112. Xu, Y.H.; Zhou, Y.; Li, R.X. Simultaneous fluorescence response and adsorption of functionalized Fe3O4@SiO2 nanoparticles to Cd2+, Zn2+ and Cu2+. Colloids Surf. A Physicochem. Eng. Asp. 2014, 459, 240-246. [CrossRef]

113. Chen, Q.; Hu, W.; Sun, C.; Li, H.; Ouyang, Q. Synthesis of improved upconversion nanoparticles as ultrasensitive fluorescence probe for mycotoxins. Anal. Chim. Acta 2016, 938, 137-145. [CrossRef]

114. Liu, Z.; Koczera, P.; Doleschel, D.; Kiessling, F.; Gatjens, J. Versatile synthetic strategies for PBCA-based hybrid fluorescent microbubbles and their potential theranostic applications to cell labelling and imaging. Chem. Commun. (Camb.) 2012, 48, 5142-5144. [CrossRef]

115. Chang, L.; Chen, S.; Jin, P.; Li, X. Synthesis of multifunctional fluorescent magnetic graphene oxide hybrid materials. J. Colloid Interface Sci. 2012, 388, 9-14. [CrossRef]

116. Hua, X.; You, H.; Luo, P.; Tao, Z.; Chen, H.; Liu, F.; Wang, M. Upconversion fluorescence immunoassay for imidaclothiz by magnetic nanoparticle separation. Anal. Bioanal. Chem. 2017, 409, 6885-6892. [CrossRef]

117. Jin, M.; Liu, X.; van den Berg, A.; Zhou, G.; Shui, L. Ultrasensitive DNA detection based on two-step quantitative amplification on magnetic nanoparticles. Nanotechnology 2016, 27, 335102. [CrossRef] [PubMed]

118. Li, N.; Gao, Z.F.; Kang, B.H.; Li, N.B.; Luo, H.Q. Sensitive mutant DNA biomarker detection based on magnetic nanoparticles and nicking endonuclease assisted fluorescence signal amplification. RSC Adv. 2015, 5, 20020-20024. [CrossRef]

119. Quarta, A.; Bernareggi, D.; Benigni, F.; Luison, E.; Nano, G.; Nitti, S.; Cesta, M.C.; Di Ciccio, L.; Canevari, S.; Pellegrino, T.; et al. Targeting FR-expressing cells in ovarian cancer with Fab-functionalized nanoparticles: a full study to provide the proof of principle from in vitro to in vivo. Nanoscale 2015, 7, 2336-2351. [CrossRef] [PubMed]

120. Portnoy, E.; Polyak, B.; Inbar, D.; Kenan, G.; Rai, A.; Wehrli, S.L.; Roberts, T.P.; Bishara, A.; Mann, A.; Shmuel, M.; et al. Tracking inflammation in the epileptic rat brain by bi-functional fluorescent and magnetic nanoparticles. Nanomedicine 2016, 12, 1335-1345. [CrossRef]

121. Wan, Y.; Sun, Y.; Qi, P.; Wang, P.; Zhang, D. Quaternized magnetic nanoparticles-fluorescent polymer system for detection and identification of bacteria. Biosens. Bioelectron. 2014, 55, 289-293. [CrossRef]

122. Wang, S.; Zheng, L.; Cai, G.; Liu, N.; Liao, M.; Li, Y.; Zhang, X.; Lin, J. A microfluidic biosensor for online and sensitive detection of Salmonella typhimurium using fluorescence labeling and smartphone video processing. Biosens. Bioelectron. 2019, 140, 111333. [CrossRef]

123. Wang, Y.; Sun, H.; Li, R.; Ke, P.; Zhu, H.; Guo, H.; Liu, M.; Sun, H. An immunomagnetic separation based fluorescence immunoassay for rapid myoglobin quantification in human blood. Anal. Methods 2016, 8,7324-7330. [CrossRef]

124. Niazi, S.; Wang, X.; Pasha, I.; Khan, I.M.; Zhao, S.; Shoaib, M.; Wu, S.; Wang, Z. A novel bioassay based on aptamer-functionalized magnetic nanoparticle for the detection of zearalenone using time resolved-fluorescence NaYF4: Ce/Tb nanoparticles as signal probe. Talanta 2018, 186, 97-103. [CrossRef]

125. Shen, T.; Yue, Q.; Jiang, X.; Wang, L.; Xu, S.; Li, H.; Gu, X.; Zhang, S.; Liu, J. A reusable and sensitive biosensor for total mercury in canned fish based on fluorescence polarization. Talanta 2013, 117, 81-86. [CrossRef]

126. Shrivastava, S.; Lee, W.-I.; Lee, N.-E. Culture-free, highly sensitive, quantitative detection of bacteria from minimally processed samples using fluorescence imaging by smartphone. Biosens. Bioelectron. 2018, 109, 90-97. [CrossRef]

127. Yao, Q.; Zheng, Y.; Cheng, W.; Chen, M.; Shen, J.; Yin, M. Difunctional fluorescent HSA modified CoFe 2 O 4 magnetic nanoparticles for cell imaging. J. Mater. Chem. B 2016, 4, 6344-6349. [CrossRef]

128. Wen, D.; Liu, Q.; Cui, Y.; Kong, J.; Yang, H.; Liu, Q. DNA based click polymerization for ultrasensitive IFN- $\gamma$ fluorescent detection. Sens. Actuators B Chem. 2018, 276, 279-287. [CrossRef]

129. De La Rosa-Romo, L.M.; Oropeza-Guzmán, M.T.; Olivas-Sarabia, A.; Pina-Luis, G. Flavone functionalized magnetic nanoparticles: A new fluorescent sensor for $\mathrm{Cu} 2+$ ions with nanomolar detection limit. Sens. Actuators B Chem. 2016, 233, 459-468. [CrossRef]

130. Luo, S.; Liu, Y.; Rao, H.; Wang, Y.; Wang, X. Fluorescence and magnetic nanocomposite Fe3O4@ SiO2@ Au MNPs as peroxidase mimetics for glucose detection. Anal. Biochem. 2017, 538, 26-33. [CrossRef] [PubMed] 
131. Amini, B.; Kamali, M.; Salouti, M.; Yaghmaei, P. Fluorescence bio-barcode DNA assay based on gold and magnetic nanoparticles for detection of Exotoxin A gene sequence. Biosens. Bioelectron. 2017, 92, 679-686. [CrossRef]

132. Ma, L.; Sun, N.; Meng, Y.; Tu, C.; Cao, X.; Wei, Y.; Chu, L.; Diao, A. Harnessing the affinity of magnetic nanoparticles toward dye-labeled DNA and developing it as an universal aptasensor revealed by lipopolysaccharide detection. Anal. Chim. Acta 2018, 1036, 107-114. [CrossRef]

133. Kim, S.; Ko, J.; Lim, H.B. Application of magnetic and core-shell nanoparticles to determine enrofloxacin and its metabolite using laser induced fluorescence microscope. Anal. Chim. Acta 2013, 771, 37-41. [CrossRef]

134. Zarei-Ghobadi, M.; Mozhgani, S.H.; Dashtestani, F.; Yadegari, A.; Hakimian, F.; Norouzi, M.; Ghourchian, H. A genosensor for detection of HTLV-I based on photoluminescence quenching of fluorescent carbon dots in presence of iron magnetic nanoparticle-capped Au. Sci. Rep. 2018, 8, 15593. [CrossRef]

135. Ma, Y.; Zheng, B.; Zhao, Y.; Yuan, H.; Cai, Y.; Du, J.; Xiao, D. A sensitive and selective chemosensor for GSSG detection based on the recovered fluorescence of NDPA-Fe(3)O(4)@SiO(2)-Cu(II) nanomaterial. Biosens. Bioelectron. 2013, 48, 138-144. [CrossRef]

136. Xue, Q.; Wang, L.; Jiang, W. A versatile platform for highly sensitive detection of protein: DNA enriching magnetic nanoparticles based rolling circle amplification immunoassay. Chem. Commun. (Camb.) 2012, 48, 3930-3932. [CrossRef]

137. Yu, X.; Wen, C.Y.; Zhang, Z.L.; Pang, D.W. Control of magnetic field distribution by using nickel powder@PDMS pillars in microchannels. RSC Adv. 2014, 4, 17660-17666. [CrossRef]

138. Song, E.Q.; Hu, J.; Wen, C.Y.; Tian, Z.Q.; Yu, X.; Zhang, Z.L.; Shi, Y.B.; Pang, D.W. Fluorescent-magnetic-biotargeting multifunctional nanobioprobes for detecting and isolating multiple types of tumor cells. ACS Nano 2011, 5, 761-770. [CrossRef] [PubMed]

139. Xie, H.Y.; Xie, M.; Zhang, Z.L.; Long, Y.M.; Liu, X.; Tang, M.L.; Pang, D.W.; Tan, Z.; Dickinson, C.; Zhou, W. Wheat germ agglutinin-modified trifunctional nanospheres for cell recognition. Bioconjug. Chem. 2007, 18, 1749-1755. [CrossRef] [PubMed]

140. Xie, H.Y.; Zuo, C.; Liu, Y.; Zhang, Z.L.; Pang, D.W.; Li, X.L.; Gong, J.P.; Dickinson, C.; Zhou, W. Cell-targeting multifunctional nanospheres with both fluorescence and magnetism. Small 2005, 1, 506-509. [CrossRef]

141. Reich, G. Near-infrared spectroscopy and imaging: basic principles and pharmaceutical applications. Adv. Drug Deliv. Rev. 2005, 57, 1109-1143. [CrossRef]

142. Sakudo, A. Near-infrared spectroscopy for medical applications: Current status and future perspectives. Clin. Chim. Acta 2016, 455, 181-188. [CrossRef]

143. Roggo, Y.; Chalus, P.; Maurer, L.; Lema-Martinez, C.; Edmond, A.; Jent, N. A review of near infrared spectroscopy and chemometrics in pharmaceutical technologies. J. Pharm. Biomed. Anal. 2007, 44, 683-700. [CrossRef]

144. Büning-Pfaue, H. Analysis of water in food by near infrared spectroscopy. Food Chem. 2003, 82, 107-115. [CrossRef]

145. Yang, H.M.; Park, C.W.; Park, S.; Kim, J.D. Cross-linked magnetic nanoparticles with a biocompatible amide bond for cancer-targeted dual optical/magnetic resonance imaging. Colloids Surf. B Biointerfaces 2018, 161, 183-191. [CrossRef]

146. Wu, H.; Cheng, K.; He, Y.; Li, Z.; Su, H.; Zhang, X.; Sun, Y.; Shi, W.; Ge, D. Fe3O4-based multifunctional nanospheres for amplified magnetic targeting photothermal therapy and Fenton reaction. ACS Biomater. Sci. Eng. 2018, 5, 1045-1056. [CrossRef]

147. Gollavelli, G.; Ling, Y.C. Magnetic and fluorescent graphene for dual modal imaging and single light induced photothermal and photodynamic therapy of cancer cells. Biomaterials 2014, 35, 4499-4507. [CrossRef] [PubMed]

148. Wu, L.; Zong, L.; Ni, H.; Liu, X.; Wen, W.; Feng, L.; Cao, J.; Qi, X.; Ge, Y.; Shen, S. Magnetic thermosensitive micelles with upper critical solution temperature for NIR triggered drug release. Biomater. Sci. 2019, 7, 2134-2143. [CrossRef] [PubMed]

149. Jin, X.; Zhang, M.; Gou, G.; Ren, J. Synthesis and Cell Imaging of a Near-Infrared Fluorescent Magnetic "CdHgTe-Dextran-Magnetic Layered Double Hydroxide-Fluorouracil” Composite. J. Pharm. Sci. 2016, 105, 1751-1761. [CrossRef] [PubMed] 
150. Zhou, H.; Hou, X.; Liu, Y.; Zhao, T.; Shang, Q.; Tang, J.; Liu, J.; Wang, Y.; Wu, Q.; Luo, Z.; et al. Superstable Magnetic Nanoparticles in Conjugation with Near-Infrared Dye as a Multimodal Theranostic Platform. ACS Appl. Mater. Interfaces 2016, 8, 4424-4433. [CrossRef]

151. Zhou, Z.; Chen, H.; Lipowska, M.; Wang, L.; Yu, Q.; Yang, X.; Tiwari, D.; Yang, L.; Mao, H. A dual-modal magnetic nanoparticle probe for preoperative and intraoperative mapping of sentinel lymph nodes by magnetic resonance and near infrared fluorescence imaging. J. Biomater. Appl. 2013, 28, 100-111. [CrossRef]

152. Huang, P.; Li, Z.; Lin, J.; Yang, D.; Gao, G.; Xu, C.; Bao, L.; Zhang, C.; Wang, K.; Song, H.; et al. Photosensitizer-conjugated magnetic nanoparticles for in vivo simultaneous magnetofluorescent imaging and targeting therapy. Biomaterials 2011, 32, 3447-3458. [CrossRef]

153. Cho, S.H.; Kim, A.; Shin, W.; Heo, M.B.; Noh, H.J.; Hong, K.S.; Cho, J.H.; Lim, Y.T. Photothermal-modulated drug delivery and magnetic relaxation based on collagen/poly(gamma-glutamic acid) hydrogel. Int. J. Nanomedicine 2017, 12, 2607-2620. [CrossRef]

154. Lee, H.; Choi, H.; Lee, M.; Park, S. Preliminary study on alginate/NIPAM hydrogel-based soft microrobot for controlled drug delivery using electromagnetic actuation and near-infrared stimulus. Biomed. Microdevices 2018, 20, 103. [CrossRef]

(C) 2019 by the authors. Licensee MDPI, Basel, Switzerland. This article is an open access article distributed under the terms and conditions of the Creative Commons Attribution (CC BY) license (http://creativecommons.org/licenses/by/4.0/). 